\title{
Studies on the Salivary Glands of Rice Plant Leafhoppers
}

\author{
I. Morphology and Histology \\ By Kazushige Sōgawa \\ Laboratory of Applied Entomology and Nematology, Faculty of Agriculture, \\ Ncroya University, Anjô, Aichi
}

\section{INTRODUCTION}

The salivary glands of Hemiptera are considerably important in relation to transmitting virus infections, and to secreting plant. injuring substances known to induce various symptoms to the plant (CARTER, 1962). In the course of studies which deal with such subjects, the knowledge of anatomy of the salivary glands is very essential for better consideration of their functions. In Heteroptera, their morphology has been studied by Bugnion and Popoff $(1908,1910)$, BAptist (1941), Southwood(1955), NuORTEVA (1956), and Miyamoto (1961). However, such studies in case of leafhoppers are fragmental and limited since the publication of the papers of BUGNION (1907), BUGNION and PopofF (1908, 1910), Dobroscky (1931), Willis (1949), Saxena (1955), Nuorteva (1956 a), NASU (1963), and Gil-FernAndeZ (1965), and there is still dearth of knowledge particularly in relation to the function of the salivary glands. From various works, it is assumed that the salivary glands of leafhoppers have at least two functions concerned with feeding; one is to secrete digestive enzymes (HERFORD, 1935; SAXENA, 1954; NUORTEVA, 1956 a ; etc.), and the other one is to produce materials to form the stylet sheath (SMith, 1933; Storey, 1939; DAY et al., 1952 ; etc.). This may be supported by Miles' works (1959, 1960, 1960 a) on the physiology of the salivary secretions of Oncopeltus.

Keeping the above facts in mind, the present investigations were undertaken to study morphology and histology of the salivary glands of rice plant leafhoppers.

\section{MATERIALS AND METHODS}

Examined species The following species were examined mainly in adult stage unless otherwise stated:- Nephotettix cincticeps UHLER (Deltocephalidae), Inazuma dorsalis MotSchULSKY (Deltocephalidae), Tettigella viridis LINNÉ (Tettigellidae), Laodelphax striatellus FALLÉN (Delphacidae), Sogatella frucifera Horváth (Delphacidae), and Nilaparvata lugens STÅ (Delphacidae). These insects were collected from paddy fields in Anjô city, Aichi Prefecture in 1964. The insects which have been successively reared for some generations on rice plant in cabinet were also used. In addition, the species given below were employed for comparative study of the salivary glands:-Macrosteles fascifrons ST A L (Deltocephalidae), Hishimonus sellatus UHLER (Deltocephalidae), Usuironus limbifer MATsUMURA (Deltocephalidae), Bothrogonia japonica IsHIHARA (Tettigellidae), Chlorita flavescens FABRICIUS(Cicadellidae), Erythroneura limbata Matsumura (Cicadellidae), Tropidocephala brunnipennis Signoret (Delphacidae), Stenocranus minutus FABRICIUS (Delphacidae), Delphax crassicornis PANZER (Delphacidae), and Delphacodes albifascia MATSUMura (Delphacidae).

Method for morphological studies The salivary glands were dissected from live insects into CLARKE's solution (Formula: distilled water $200 \mathrm{ml}, \mathrm{NaCl} 1.3 \mathrm{~g}, \mathrm{KCl} 0.028 \mathrm{~g}, \mathrm{CaCl}_{2}$ $0.024 \mathrm{~g}, \mathrm{NaHCO}_{3} 0.02 \mathrm{~g}, \mathrm{Na}_{2} \mathrm{HPO}_{4} 0.002 \mathrm{~g}$ ). Then, a droplet of $1 \%$ toluidine blue or

(Received for publication, July 14, 1965) 
neutral red solution was added to the CLARKE's solution in order to stain the glands supravitally. Stained salivary glands were removed on a slide glass by capillary pipette, mounted with the fresh CLARKE's solution, and observed under the microscope. Unstained salivary glands were also observed for comparison.

Method for histological studies The head parts of the insects, where the salivary glands were involved, were fixed with Bouin, Allen-Bouin, or Susa fluids. After fixation the materials were treated with $5 \%$ trichloroacetic acid in $85 \%$ ethyl alcohol in order to soften cuticle, when neccessary. Dehydration of the materials was carried out through the series of mixtures of $n$-butyl and ethyl alcohols. To prevent hardening of cuticle $n$-butyl alcohol was used as a clearing agent. Then the materials were embedded in paraffin wax (m.p. $56-58^{\circ} \mathrm{C}$ ), and sectioned at $10-12 \mu$ thickness. The sections were stained by Schleichl's azan or Delafield's hematoxyline-eosin staining methods, mounted with Canada balsam following the common procedure, and observed under the light microscope.

\section{RESULTS}

\section{General features of salivary system}

The whole salivary glands are pale lacteal or translucent, and are situated within cranium and prothrax region. It consists of two pairs of glands, namely principal glands (PG) and accessory glands (AG). The principal gland much larger in size and more complicated in structure than the accessory gland. Between the superfamilies, Cicadelloidea and Fulgoroidea, their structures are quite different. Their diagramatic morphologies were shown in Text-Fig. 1 together with the tentative terms and signs used in this paper. A principal duct $(\mathrm{PD})$ arises from the junction of lobes or follicles consisting the principal gland, and conglutinates with the duct from the opposite gland to form a salivary duct (SD) which opens into the salivary pump. Each principal duct also receives an accessory duct (AD) arising from the accessory gland

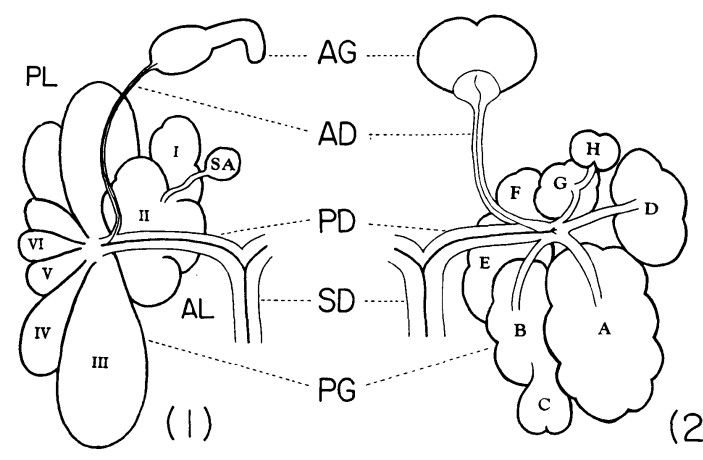

Text-Fig. 1. Diagrams showing the fundamental structure of the salivary glands of Deltocephalidae (1) and Delphacidae (2)

$\mathrm{AD}$, accessory duct; $\mathrm{AG}$, accessory gland; $\mathrm{PD}$, principal duct. PG, principal gland; SD, salivary duct.

I-VI, type of the cells consisting the principal gland.

$\mathrm{AL}$, anterior lobe; $\mathrm{PL}$, posterior lobe; SA, small spherical appendage.

A-H, type of the follicle consisting the principal gland.

close to the opening of the principal gland. 2. Morphology of salivary glands

Nephotettix cincticeps UHLER and Inazuma dorsalis Motschlusky

a) Principal gland Morphologically there is no appreciable difference in this gland between both the species. The gland is divided into two parts which are called here "anterior lobe (AL)" and "posterior lobe (PL)" respectively. The anterior lobe is a small mass of cells found in the ventral side of the posterior lobe. Its distal region is cytologically distinguished from the proximal region. Also a small spherical appendage (SA) belongs to this lobe. The posterior lobe is mainly formed with independent six large cells which are arranged radially, and vary somewhat in shape and size from each other. In the center part of the posterior lobe, a compact mass of different sized cells is recognized, and it is definitely cleared by means of supravital staining that the mass is composed of three types of cells laid cocentrically. (P1. I, Figs. 1 and 2; Pl. IV, Figs. 1 and 2).

b) Accessory gland This gland formed by much smaller and short tubular tissue, 
which is usually bent into V-shape. The distal end is fixed on the anterior lobe of the principal gland.

c) Ducts The principal duct is moderately thick, while the accessory one is extremely slender. Internally a narrow chitinous canal runs throughout their length of the both ducts.

\section{Tettigella viridis LINNÉ}

a) Principal gland The anterior lobe is conspicuously enlarged, and ovoid in outline. Different kind of cells are recognized in the proximal region. The posterior lobe is volum. inous, and consists of three types of cells laid cocentrically. The peripheral cells which are arranged closely and radially constitute the major portion of the posterior lobe. Two independent cells are also appended at the base of this lobe. (Pl. I, Fig. 2).

b) Accessory gland This gland is typical tubular, and has swollen cephalic region from which the accessory duct starts. It is extremely convoluted within cranium.

c) Ducts Each duct closely resembles to those of $N$. cincticeps structurally.

\section{Laodelphax striatellus FALLÉn, Sogatella frucifera HoRváth and Nilaparvata lugens $\mathrm{STA} \mathrm{L}$}

a) Principal gland The principal glands of the three species have almost similer features and structures (Pl. III, Figs. 1 and $3 ; \mathrm{Pl}$. V, Figs. 4). It is a congregated body consisting of eight kinds of separated follicles, which are distinguished from each other by their shape, size and staining properties. They are respectively labelled in alphabetic order from $\mathrm{A}$-follicle to $\mathrm{H}$-follicle in this paper (Text-Fig. 1-2). Each follicle is composed of small number of cells and possess a short ducteole converging to the opening part of the principal duct. The A-follicle is the largest and ovoid in shape. On the ventral side of this follicle the elongated ovoid B-follicle is observed. The C-follicle which is formed by only two cells is situated adjacently to the distal end of the B-follicle. The kidney-shaped D-follicle with longer ductiole is behind the A-follicle. The hemispherical larger E-follicle is located close to the smaller F-follicle which is situated nearest to the opening region of the principal duct. Both the $\mathrm{G}$ - and $\mathrm{H}$-follicles lie anteriorly and are connected with each other by single ducteole.

b) Accessory gland It is a bi-cellular gland somewhat constricted spherical in shape, and situated anteriorly towards cranium.

c) Ducts The principal duct is straight and moderately thick. The epithelium of the salivary duct is usually much thicker than that of the principal duct. The accessory duct is more slender than the principal duct, but not so slender as that of $N$. cincticeps.

\section{Compatative morphology of salivary glands}

According to Southwood (1955), the structures of the salivary glands are reasonably constant at infra-familial levels in terrestrial Heteroptera. In the present studies, the salivary glands of both $N$. cincticeps and $I$. dorsalis possess close resemblance in structure. However, the glands of $T$. viridis bore striking difference to those of the abovementioned species. Also, among the three species of Delphacids examined no appreciable difference in structure of their salivary glands was recognized. To determine whether these similarities and differences of the salivary glands' structures depend on the taxonomic relationships of the species or on feeding habits, the studies on comparative morphology of the salivary glands of several different leafhoppers were undertaken. The shape and size of the examined salivary glands are illustrated in Plate II, Figs. 1 7; Plate III, Figs. 4 6; and Plate V, Fig. 3. Their synoptic descriptions are as follows:-

1. Deltocephalidae

Macrosteles fascifrons STÅ (PI. II, Fig. 4). Anterior lobe small, divided into two regions; six III-cells strikingly different in size, IVcells moderately large, V- and VI-cells extremely small; accessory gland straight small rod-like in form.

Hishimonus sellatus UHLER (Pl. II, Fig. 5). Anterior lobe with at least three regions, the 
distal region composed of several tiny cells arranged longitudinally, in the medium region large oval cells arranged radially, the proximal region of moderately small cells; III-cells dominant, V-cells well defined; accessory gland consists of sharply bent short tubular.

Usuironus limbifer MATSUMURA (Pl. II, Fig. 3). Anterior lobe large conspicously, with two regions, the distal region made up of a large number of small cells; posterior lobe similar to that of $N$. cincticeps; accessory gland consists of sharply bent somewhat long tubule.

\section{Tettigellidae}

Bothrogonia japonica IsHIHARA (Pl. II, Figs. 1 and 2). Distal cells of anterior lobe degenerated into four extremely small cells; posterior lobe resembles to that of T.viriais; sinuate tail portion of accessory gland more slender and short. The epithelial cells of the principal duct include fine granules stained in purple with toluidine blue in its intermediate zone. Also a vertically striated zone stained in faint purple with toluidine blue occurs around the chitinous lining of the accessory duct.

\section{Cicadellidae}

Chlorita flavescens FABRIcIUS (Pl. II, Fig. 6) and Erythroneura limbata MATsumuRA (P1 II, Fig. 7). Ovoid anterior lobe formed by single kind of cells; posterior lobe consists of two independent cells and a compact mass made up of two kinds of cells; accessory gland elongated, thick and tubular.

\section{Delphacidae}

Tropidocephala brunnipennis SIGNORET (P1. III, Fig. 5), Stenocranus minutus FABRICIUS (Pl. V, Fig. 3), Delphax crassicornis PANZER (P1. III, Fig. 6), and Delphacodes albifascia Matsumura (Pl. III, Fig. 4). The whole structures of salivary glands from these species closely resemble to those of the rice plant Delphacids examined.

\section{Histology of salivary glands}

Histological studies were undertaken to confirm the supposition that the principal gland is complicatedly composed of several kinds of secretory cells, and explore the detail structures and functions of the accessory gland and duct. $N$. cincticeps, $T$. viridis and L. striatellus were examined. The description of coloration was based on the results obtained by azan staining method, unless otherwise stated.

\section{Nephotettix cincticeps UHLER}

a) Principal gland The anterior lobe is made up of two masses of different kinds of cells, which were respectively called I-cells (I) and II-cells (II). The posterior lobe also consists of four kinds of secretory cells, which were termed numerically from III-cells (III) to VI-cells (VI) in this paper (Text-Fig. 11). All of these cells are binucleated, and merocrine type of secretory cells which remain intact with the secretion. Their secretory canaliculi always occupy an intracellular position and form a loose network between the most peripheral zone of the cell and nuclei. Their cytoplasmic structures and arrangement were illustrated diagramatically in Text-Fig. 2, and their characteristics were summarised in Table 1. In Plate VI the photographs of their histological sections are shown.

The proximal region of the anterior lobe is formed by two layers of the II-cells. Each layer consists of six cells arranged radially. The cells of the lawer layer is smaller than those of the upper layer. The cytoplasm of the II-cells is opaque and stained in bluish purple with toluidine blue in saline solution. In the histological sections the cytoplasm is moderately granular and dense. It tends to be stained reddish, but partly blue. No stainable material is recognized within the sinuous intracellular canaliculi of this type of cells. The distal region of the anterior lobe is made up of the three I-cells whose cytoplasm is irregularly vacuolated and carminophil. In CLARKE's solution these cells are translucent, and stained strongly with neutral red. In addition, the content of their intracellular canaliculi is selectively colored in purple with toluidine blue. The I-cells have asteroid nuclei. The small spherical appendage is a compact mass of small 


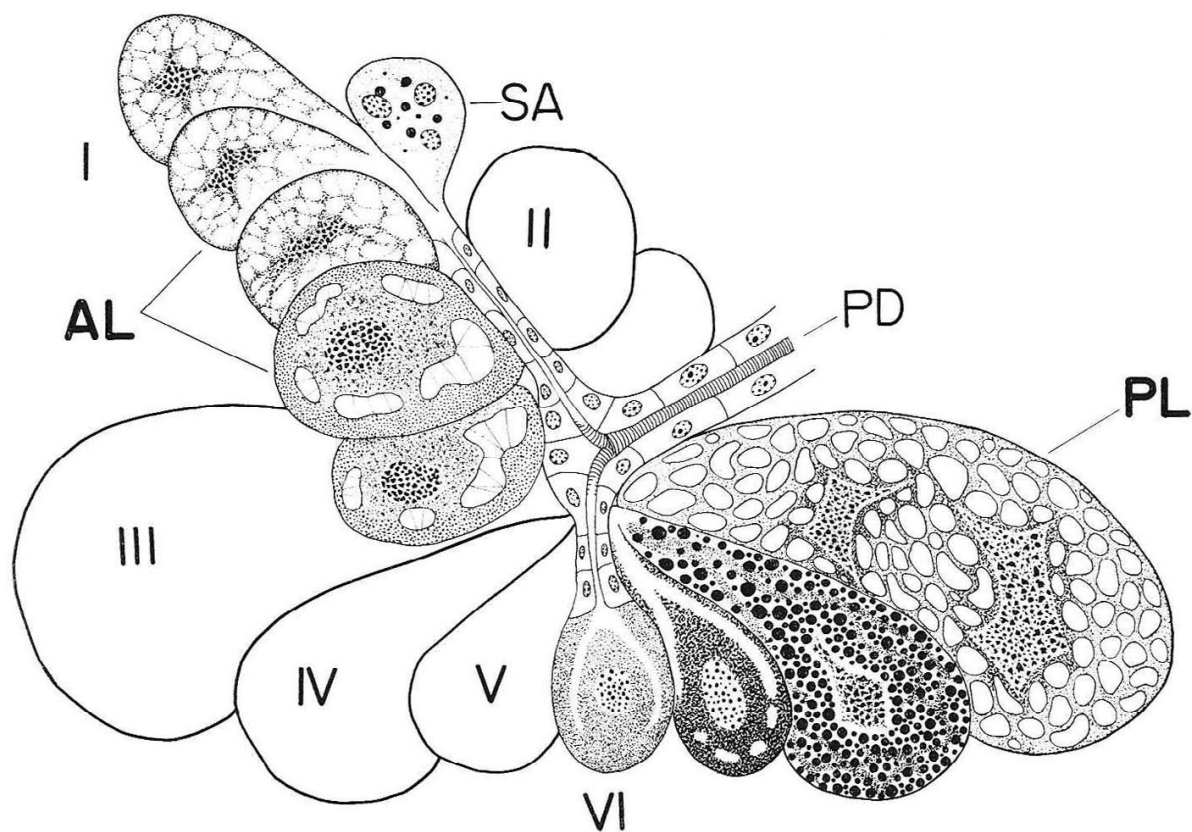

Text-Fig. 2. Diagramatic section of the principal gland of $N$. cincticeps, showing the cytological characteristics of the various types of the cells

number of cells, whose cytoplasm is stained in purplish gray and contains carminophil granules. Spherical nuclei are found in it. A slender ducteole arise from the appendage that seems to run into the center part of the proximal region of the lobe.

The III-cells are the largest cells among the somatic cells of this insect. They are six in number and arranged radially like petals. The shape and size of these cells are somewhat variable from each other. They are translucent in saline solution, and generally stained in deep violet with toluidine blue. With neutral red supravital staining they are variably colored from yellow to reddish pink. This may indicate that each active cell is not in the same functional state at the same time. Histologically the III-cells are characterized by the thick network of their intracellular canaliculi, which occupies the great part of the cell. Under certain conditions the canaliculi are more or less distended or shrunk with coincident changes in shape and density of the nuclei. The content of the canaliculi is optically homogeneous and weakly stained in pale blue in most cases. As a rule, the cytoplasm tends to be stained in reddish purple,and contains numerous fine cytoplasmic inclusions. The neuclei, being asteroid commonly and about $140 \mu$ in length, are situated around the central part of the cell. A few neucleoli are embedded in the dense granular karyoplasm. The six medium IV-cells lie concentrically on the IIIcells. They are milky white and opaque cells, and are stained in pale light blue with toluidine blue and are weakly stained in yellow with neutral red. In the histological sections this type of cells are characteristically distinguished from others by the definite affinity for orange $G$, and the carminophilic dense granulation. The specific spherical granules vary in size even in the same cell, but no striking variation in number of such granules is recognized among the different IV-cells. On histological ground, these inclusions seems to be secretion precursors. The intracellular canaliculi which penetrate the cytoplasm in coarse reticular manner is usually filled with homogenous substance with intensive affinity for aniline blue, but appear to be free from it in certain cases. The nuclei, being about 
Table 1. Histological properties of the principal gland's cells of $N$. cincticeps (Deltocephalidae)

\begin{tabular}{|c|c|c|c|}
\hline $\begin{array}{l}\text { Type of } \\
\text { cell }\end{array}$ & $\begin{array}{l}\text { Number } \\
\text { of cell }\end{array}$ & $\begin{array}{l}\text { Toluidine blue } \\
\text { supravital stain }\end{array}$ & Cytoplasmic features \\
\hline $\mathrm{I}$ & 3 & purple (cont.) & coarse and reticular \\
\hline II & 12 & bluish purple & moderatly granular \\
\hline III & 6 & deep violet & $\begin{array}{l}\text { greatly occupied with } \\
\text { canaliculi }\end{array}$ \\
\hline IV & 6 & pale light blue & crowded with granules \\
\hline $\mathrm{V}$ & 6 & $\begin{array}{l}\text { deep blue often } \\
\text { purple }\end{array}$ & filled with fine granules \\
\hline $\mathrm{VI}$ & 2 & purple(cont.) & fine granular \\
\hline
\end{tabular}

Coloration of cytoplasmic
structures

cyt. red

cyt. reddish or blue

cyt. reddish purple cont. faint blue

cyt. orange, gr. red cont. blue

gr. blue

cyt. purple
$100 \mu$ in length, are elongated amoeboid in shape. In the center part of the IV-cells the six small V-cells are localized. Unlike the IV-cells, the V-cells show strong staining characteristic for aniline blue. Their cytoplasm is uniformly filled with minute granules which are selectively stained in deep blue or often purple with toluidine blue. Small spherical or ovoid nuclei, being about $40 \mu$ in diameter, are situated about the middle of the cells. The two VI-cells are embedded in the center region of the posterior lobe. They are more or less smaller than the V-cells. Their cytoplasm is fine granular, and generally stained in purpule. Their nuclei resemble to those of the $\mathrm{V}$-cells.

b) Accessory gland The gland is differentiated into two distinct regions, namely "head portion" and "tail portion". The histological change occurs abruptly at the junction point of the both portions.

Head portion This portion is formed by polyhedral cells surrounding narrow cavity, which may be obscure in $N$. cincticeps. In any cross section five such cells are usually visible (Pl. IV, Fig. 1). The apical part of each cell is hollow hemispherically. Palely stainable material is recognized frequently within the hollows. Each cell contains two prominent oval nuclei with granular chromatin, and the cytoplasm is dense and strongly stained in red.

Tail portion This portion has a lumen surrounded by a layer of cells (Pl. IV, Figs. 2 and 3 ). These cells seem to be provided with a distinct striated border, being irregularly infolded. The cytoplasm of the epithelial cells is strongly stained in purplish red in its most peripheral zone, but weakly in the intermediate zone. Small spherical or ovoid nuclei are found scattered. Contents of the lumen are aqueous and not fixed.

c) Ducts It appears in cross section that two epithelial cells make up the wall of the principal duct. The inner border of the duct is lined with a chitinous intima which forms a narrow ejaculatory canal. The epithelial cells are divided into three reasonably distinct zones (Pl. IV, Figs. 7 and 8). From the outside of the duct towards the chitinous lining the three zones include:- a basal, an intermediate and an apical zone. The basal zone is the peripheral part of the cell where the cytoplasm is extremely dense and stained intensely. The intermediate zone contains nuclei which are somewhat flattened and oval in shape. The cytoplasm of this zone is fine granular, and is stained moderatly weak. 
In the apical zone numerous fine striations occur vertically to the chitinous lining. This zone is otherwise stained in blue or purple. The principal duct is bifurcated into two short and slender ducteoles at the junction point of both the lobes of the principal gland. Each ducteole is inserted intercellularly into the center part of the radially arranged cells of each lobe. The epithelium is extremely thin and unstainable. The chitinous lining disapperes in the ducteoles. On the other hand, the accessory duct is simple in structure. A chitinous lining, about half the diameter of that of the principal duct, is merely covered with a membraneous epithelium (P1. IV, Fig. 9).

\section{Tettigella viridis LINNÉ}

In the principal gland, remarkable cytological differences were recognized in the distal I-cells of the anterior lobe and the III-cells between $N$. cincticeps and $T$. viridis, but none in the rest. Also, in $N$. cincticeps, it is the III-cells that constitute the major portion of the posterior lobe, but it is the IV-cells in $T$. viridis. The cytological structures and the arrangement of various kinds of secretory cells were illustrated diagramatically in TextFig. 3. The photographs of their histological sections are shown in Plates VII and IX.

a) Principal gland Two regions are distinguished in the anterior lobe on the basis of cytological difference. The distal region is markedly enlarged in this species, and take the form of voluminous ovoid body in outline. This region is made up of eight large secretory cells, the I-cells (Pl. VII, Fig. 1), which are tightly massed, but the boundaries among them are distinct. The tapered apical part of each cell is inserted into the center part of the proximal region of this lobe to connect with the secretory ducteole. The cytoplasm of the I-cells is minute granular, and stained in reddish purple. Normally it also contains numerous small aqueous vacuoles. Each cell is binucleated. The nuclei are elongated typical asteroid in form, and their karyoplasm is dark and fine granular. The thick intracellular canaliculi exist throughout the cytoplasm. Generally, the optically homogeneous substance stained light blue is accumulated

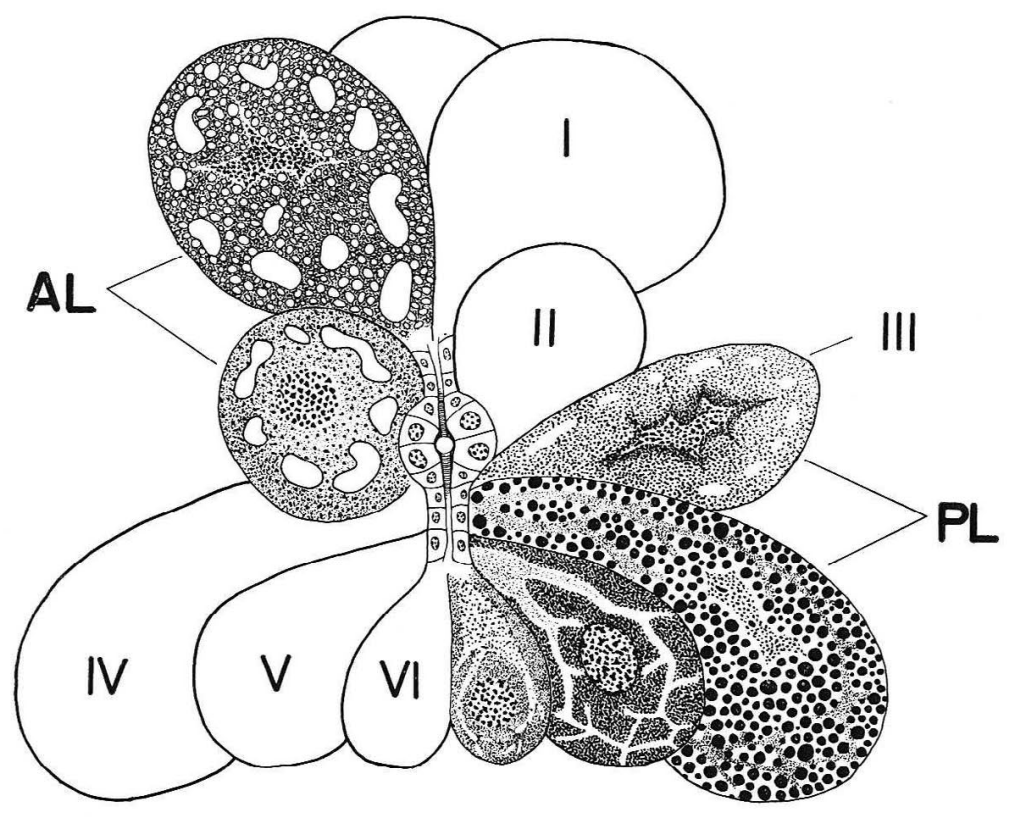

Text-Fig. 3. Diagramatic section of the principal gland of $T$. viridıs, showing the cytological characteristics of the various types of cells 
within the canaliculi. The proximal region of the anterior lobe is composed of several II-cells (Pl. VII, Fig. 2) which are round or ovoid in shape. They are arranged radially in a single layer. Their cytoplasm is moderately coarse and stained in variable reddish. Two ovoid nuclei containing highly chromatin granules are situated centrally in the cell. The secretory canaliculi form a loose network between the surface and nuclei, and are variable in thickness depending on the secretory activity of the cell. In many cases, the canaliculi are filled with finely reticulate content that stains in pale blue.

The posterior lobe consists of four types of secretory cells, which are arranged in the same manner as those of $N$. cincticeps. However, the III-cells (Pl. VII, Fig. 3) are markedly diminished in size and number, and are found as moderately small independent two cells at the basal region of the posterior lobe. Their cytoplasm is moderately homogeneous and basophilic. Two asteroid nuclei stained in deep red are situated centrally in the cell. The sinuated intracellular canaliculi run through the peripheral zone of the cytoplasm. Their content is not preserved during fixation procedure. The cytological characteristics of the other types of cells are almost the same to those of $N$. cincticeps. However, each type of cells are found twice in number than those of the above-mentioned species. The twelve numbers of IV-cells (Pl. VII, Fig. 4) which are the largest cells in the posterior lobe are acidophil and contain usually abundant carminophilic granules similar to the cells of $N$. cincticeps. The granules are definitely larger than those of $N$. cincticeps. The cytoplasm of the V-cells (Pl. VII, Fig. 5), being twelve in number, is finely and uniformely granulated and shows basophil. The coarse network of the intracellular canaliculi is definite, which is often swollen and provided with a wide cavity at the apical region of the cells. The contents are colloidal substance stained in pale blue. The four VI-cells (Pl. VII, Fig. 6) are distinguished from the V-cells by their being amphophilic and possessing moderately light cytoplasm. Their intracellular canaliculi are considerably thick and contain minutely reticulate material that stains in weak blue.

b) Accessory gland This gland of T. viridis has certain resemblances to that of $N$. cincticeps, although they are morphologically quite different from each other. Its swollen and opaque portion is a compact mass of somewhat cuneiform cells which are arranged radially leaving a narrow lumen (Pl. IV, Fig. 4). The apical part of the cells is hollowed and gets different stain of blue from the remaining part that is stained in deep red. The extremely elongated and translucent tail portion is provided with wide lumen. The wall is made up of a layer of thin epithelial cells which are fairly uniform in thickness throughout the length of this portion (Pl. IV, Figs. 5 and 6 ). The detailed cytological structures are similar to those of $N$. cincticeps.

c) Ducts The conducting part of the glands of $T$. viridis are histologically and cytologically similar to those of $N$. cincticeps.

\section{Laodelphax siriatellus FALLÉN}

a) Principal gland It was revealed by means of the supravital staining with toluidine blue, and SCHLEICHEL's azan, and DELAFIELD's hematoxyline-eosine staining method that the eight kinds of follicles of the principal gland showed quite different cytological appearances. The result was summarized in Table 2, and diagrammatically illustrated in Text-Fig. 4. Also histological photographs were shown in Plates VIII and X. The Afollicle is the largest tissue in the principal gland. It is milky white and opaque in saline solution, and stained supravitally in light blue with toluidine blue. Histologically this follicle is a mass of the same kind of eight secretory cells whose acidophilic cytoplasm is uniformly filled with a number of spherical granules. The granules are stainable with azocarmine and eosin. These granules seem to be the zymogenic granules. Their change in number is not so remarkable between the normal and the starved insects. No cell in which the granules are extremely decreased or eliminated thoroughly is found in the course of the present study. The cytological 


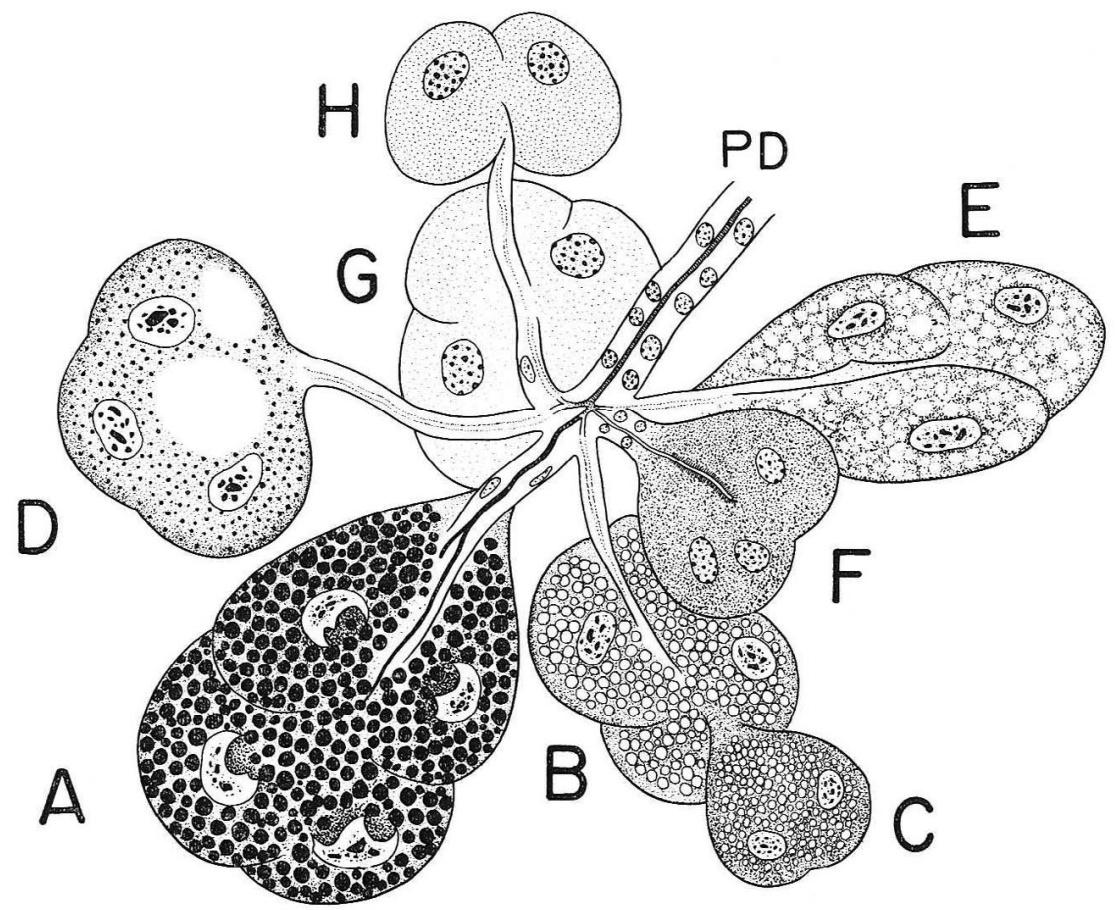

Text-Fig. 4. Diagramatic section of the principal gland of L. striatellus, showing the cytological characteristics of the various types of follicle

appearance of A-follicle is very similar to that of the V-cells of $N$.cincticeps or $T$. viridis excepting the lack of the intracellular canaliculi. It appears that the secretion products are discharged into the intercellular canaliculi and transported to the principal duct via the ducteole. The ovoid or asteroid two nuclei are situated centrally in the cell. The B-follicle is translucent and stainable in light blue with toluidine blue in saline solution. This follicle consists of binucleate four secretory cells. Their cytoplasm is stained in pale yellow with azan method, and purplish gray with hematoxyline-eosin method. It is also crowded with spherical granules which show weak cyanophil, but scarcely colored with hematoxylineeosin. The size of these granules is usually more or less smaller than those of the Afollicle. The C-follicle is made up of only two secretory cells, and the smallest follicle in the principal gland. The cytological structure of the C-follicle resembles much to that of the B-follicle. However, the granules contained in the former is always smaller in size, and show stronger cyanophilic property. The secretory cells consisting the D-follicle, being six in number, is characterized by the bluish purple coloration of their cytoplasm with hematoxyline-eosin. Also they contain a large number of minute granules which have strong affinities for hematoxyline and toluidine blue, but are not made visible by azan staining. In addition, a few large vacuoles are very often recognized in this follicle. They vary greatly in size, and contain homogeneous substance stained weakly in light blue. The E-follicle is translucent and tends to be stained in blue with toluidine blue supravital staining. In this follicle six secretory cells are recognizable. Their cytoplasm is coarse and weakly stainable in blue. Numerous aqueous vacuoles are uniformly distributed in it. The degree of the vacuolation is variable. The F-follicle shows metachromatic staining with toluidine blue as usual. The cytoplasm of the cells making up this follicle is homogeneous and finely granular, and is stained in yellowish orange. No special 
secretory elements are detected by means of azan nor hematoxyline-eosin stains. The striated zone stained in deep red occurs around the intercellular canaliculi. When the principal gland is placed in $10 \%$ formalin saline solution, the G-follicle is rapidly changed and characteristically whitened. Although the cells of this follicle is strongly stained with toluidine blue in the unfixed glands, they lack stainability by neither azan nor hematoxiline-eosin stains. Their cytoplasm is relatively dense, homogeneous, and devoid of granules and vacuoles. The $\mathrm{H}$-follicle is made up of only two cells which fail to stain supravitally with toluidine blue. Like the G-follicle their cytoplasm is not stained with the methods employed here, and its appearance is similar to that of the G-follicle. Essentially spherical, ovoid or often asteroid two nuclei are located centrally in the cells of every kinds of follicle. Their karyoplasm is granular, and contains a few nucleoli.

b) Accessory gland Next to the A-follicle of the principal gland, the accessory gland is the largest secretory tissue in the salivary system. This gland is made up of two kinds of cells; one is hemispherical main secretory cells (SC), and the other one is small nonsecretory cells called "ejective cell (EC)" here (Text-Fig. 5). The cytological appearance of the secretory cells varies strikingly depending on the stage of secretion. In certain cases, the cytoplasm is uniformly and highly filled with intense basophilic fine granules (TextFig. 5-1). The nuclei which contain numerous chromatin granules and some nucleolei are displaced towards the peripheral part of the cells, flattened extremely in shape. These features are indicative of the elaborate and accumulative stage of the secretion. In the other cases, the cytoplasm is either free from the basophilic granules or contains them scatteringly. The granules are often condensed in the apical part of the cells adjacent to the ejective cells. Also large and somewhat irregular granules, or droplets, are found in the cytoplasm, which are stained in orange. (Text-Fig. 5-2). These acidophilic granules gradually disappear with the increase of the basophlic fine granules. The nuclei are situa-

Table 2. Histological properties of the principal gland's follicles of L. striatellus (Delphacidae)

\begin{tabular}{|c|c|c|c|c|}
\hline $\begin{array}{l}\text { Type of } \\
\text { follicle }\end{array}$ & $\begin{array}{l}\text { Number } \\
\text { of cell }\end{array}$ & $\begin{array}{l}\text { Toluidine blue } \\
\text { supravital stain }\end{array}$ & Cytoplasmic features & $\begin{array}{c}\text { Coloration of cytoplasmic } \\
\text { structures }\end{array}$ \\
\hline A & 8 & pale blue & crowded with granules & $\begin{array}{l}\text { cyt. orange }(A) \\
\text { gr. red }(A), \text { pink }(H E)\end{array}$ \\
\hline B & $5^{*}$ & pale blue & crowded with granules & $\begin{array}{l}\text { cyt. purplish gray (HE) } \\
\text { gr. pale blue (A) }\end{array}$ \\
\hline $\mathrm{C}$ & 2 & pale blue & crowded with granules & $\begin{array}{l}\text { cyt. purplish gray (HE) } \\
\text { gr. light blue(A) }\end{array}$ \\
\hline $\mathrm{D}$ & 6 & deep blue & $\begin{array}{l}\text { rich in fine granules, } \\
\text { vacuolated roughly }\end{array}$ & $\begin{array}{l}\text { cyt. bluish purple (HE) } \\
\text { gr. deep blue (HE) }\end{array}$ \\
\hline $\mathrm{E}$ & 6 & blue & $\begin{array}{l}\text { coarse and vacuolated } \\
\text { uniformly }\end{array}$ & cyt. pale blue (A) \\
\hline $\mathrm{F}$ & $4^{*}$ & purple & homogeneous & cyt. yellow (A) \\
\hline $\mathrm{G}$ & 4 & deep violet & homogeneous & cyt. unstainable (A, HE) \\
\hline $\mathrm{H}$ & 2 & unstainable & homogeneous & cyt. unstainable (A, HE) \\
\hline $\begin{array}{l}* \\
\text { cyt. } \\
\text { gr. }\end{array}$ & $\begin{array}{l}\text { round } \\
\text { cytopla } \\
\text { granul }\end{array}$ & $\begin{array}{l}(\mathrm{A}) \\
(\mathrm{HE})\end{array}$ & $\begin{array}{l}\text { azan stain } \\
\text { hematoxyline-eosin stain }\end{array}$ & \\
\hline
\end{tabular}


ted about the central part of the cells, and ovoid in shape. It appears that the cells show such cytological appearance when their secretory product is discharged. The small ejective cells are closely adjacent to the apical part of the secretory cells. The terminal end of the chitinous canal of the accessory duct is inserted into these cells. Their cytoplasm around the canal is striated and stains in red. The other part of the cytoplasm is homogeneous and stains in yellow. Two spherical nuclei are centrally situated. It appears that the secretion produced by the secretory cells are discharged into the chitinous canal through the ejective cells, and the rate of secretion may be controlled by these cells.

c) Ducts A narrow chitinous canal runs throughout the conducting part. The canal is covered with a layer of epithelial cells whose detailed cytological structure is obscure in the present study.

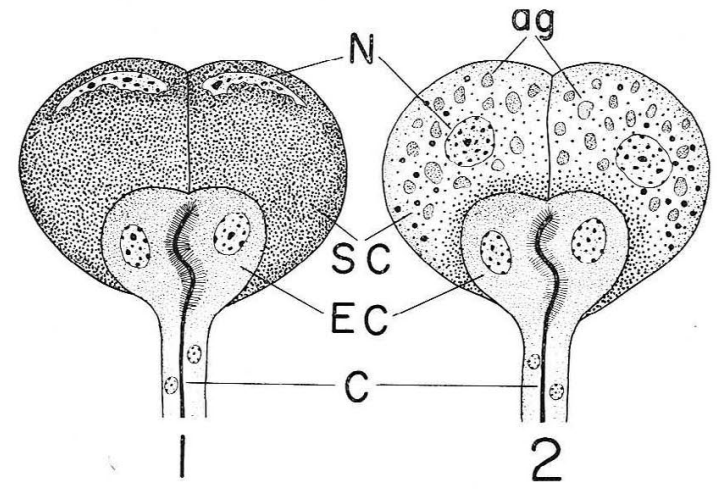

Text-Fig. 5. Diagramatic section of the accessory gland of L. striatellus, showing the cytological change of the secretory cells in different phases of secretion. C, canal; EC, ejective cell; N, nucleus; SC, secretory cell; ag, acidophilic granule.

\section{Constancy of salivary glands structure during development}

In order to ascertain whether or not structural difference of the salivary glands occurs during post-embryonic development, the glands of $T$. viridis and L. striatellus were examined in different development stages.

In both the species no striking difference is recognized at any developmental stage. The glands of the first instar nymph has already almost the same morphological fea. tures and histological structure to those of the adult excepting difference in size. The size of the glands gradually increases with the development of the nymph, and attains maximum size during the last instar stage. The glands of the last instar nymphs or adults are one and half times larger than those of the first instar nymph in general. This increase is not owing to the increase in number but in volume of the constituent cells.

\section{DISCUSSION}

\section{Variation of salivary glands structure}

On the basis of comparative morphology, the salivary glands structure of the rice plant leafhoppers could be generalized at familial level as follows:-

(A) Deltocephalidae.

1) The principal gland is a compact mass made up of six kinds of sccretory cells, and bilobed.

2) The accessory gland is of short tubular type.

(B) Delphacidae.

1) The principal gland is an aggregate body consisting of eight kinds of follicle which are made up of a small number of secretory cells.

2) The accessory gland is a bi-cellular gland.

In addition to these, the salivary glands of Tettigellidae and Cicadellidae had something in common with those of Deltocephalidae, but on the other hand, they show structural differences peculiar to each family. Within the family Deltocephalidae, the posterior lobe of the principal gland was generally constant in shape and structure, but the anterior lobe exhibited great variation. For example, the posterior lobes of $N$. cincticeps (Pl. I, Figs. 1 and 2) and $U$. limbifer (Pl. II, Fig. 3) are much similar to each other, while their anterior lobes are quite different in size and structure. The same evidence was found 
between the two species of Tettigellidae, $T$. viridis (Pl. I, Fig. 3) and B. ferruginea (Pl. II, Figs. 1 and 2). Such intra-familial variation of the anterior lobe seemed to be more attributable to the differences in feeding habits or the nature of the secretions rather than to the taxonomic relationship. In Delphacidae, in spite of definite variation in the external features of the insects examined, their salivary glands were highly constant in shape and structure. However, it has been shown that the glands represent strikingly different shape and structure in the related families such as Cixiidae, Derbidae, Meenoplidae and Flatidae (the author's unpublished investigation). From these facts, the salivary glands may be useful as criteria for major classification or phylogenic discussion in Auchenorrhyncha as has been pointed out by LESTON et al. (1954) and SouTHWOOD (1955) in Heteroptera. It is, however, doubtful whether or not the salivary glands are more valuable taxonomic criterion than the external structures of the insects.

\section{Functional differentiation in principal gland}

It is unquestionable that the principal gland is a major secretory part of the salivary glands. In Deltocephalidae and Tettigellidae, six types of secretory cells were definitely discriminated by the histological characteristics (Table 1). Also, in Delphacidae the principal gland consists of eight kinds of secretory follicle (Table 2). Histologically it strongly suggested that the functional differentiation occured in each part of the principal gland so as to elaborate two or more kinds of secretion. There are conve. nient evidences that the leafhoppers deposit the sheath material in the feeding process (e. g. Smith, 1933; Storey, 1939 ; DAy et al., 1952), and that their salivary glands contain several kinds of digestive enzyme (e. g. HERHORD, 1935 ; SAXENA, 1954 ; NUORTEVA, 1956 a). Recently Miles (1959, 1959 a) has directly proved that three species of Hemiptera secrete two types of saliva, i. e. aqueous and coagulable saliva. It is unlikely that both the types of saliva are elaborated at the same site because of their independent discharge and quite different function. In fact, MiLes (1959) has further demonstrated in Oncopeltus fasciatus (DALL.) that the coagulable sheath material originates respectively in the anterior lobe and the lateral lobe of the principal gland, while the aqueous saliva originates in the posterior lobe. Most recently NASU(1963) has also described that the cells consisting the principal gland of Nephotettix sp. can be divided into five groups cytologically, and has considered three functional differentiations among them, namely mucous, serous, and storage cells.

In view of the above facts the following conjecture was inspired:-The principal gland is a complex gland that contains at least two secretory systems, one of which elaborates the precursor of the sheath material, and the other produces the aqueous saliva containing several enzymes. However, the gland may be not made exclusively of the both systems. Discussion below refers to this conjecture.

Probable source of the sheath material In $N$. cincticeps and $T$. viridis, the V-cells of the posterior lobe usually displayed intensive basophillic characteristic i. e. being stainable with aniline blue. Besides, their cytoplasmic granules were often clearly given $\beta$-metachromasia by toluidine blue. Such staining characteristics indicate the presence of mucoid substances which seems to play a part of elaboration of the sheath material. The validity of such assumption is further strengthened by the evidence that phenolase activity relating to the chemical property of the deposited sheath has been detected at these cells in Stenicotis depressa and Eurymeloides pulchra by Miles (1964). The mucous glands considered by NASU (1963) include the IV-cells in addition to the V-cells in Nephotettix sp. In L. striatellus, no follicle regarded as probable source of the sheath material could be found by their staining property. However, the chromophobe characteristic of the coupled G- and H-follicles may be indicative of the presence of lipid substances which are the component of the sheath material (Miles, 1960, 1961).

Probable source of the aqueous saliva In 
$N$. cincticeps and $T$. viridis, the IV-cells of the posterior lobe exhibited a sharp contrast to the other kinds of cells by their characteristic affinity for orange $G$, being definite acidophil, and the numerous granular inclusions stained especially with azocarmine B. The contents of the intracellular canaliculi were proteinaceous and were stained blue. These cytological features, although circumstantial, indicates that this type of cells produce digestive enzymes, and the granules contained in their cytoplasm seem to be the zymogenic granules. The strong invertase activity detected in the posterior lobe of $T$. viridis seems to originate in these IV-cells (the author's unpublished data). In $T$. viridis the distal cells of the anterior lobe, whose cytological features were indicative of their active secretory function, were also considerable at the enzyme producing cells because of the occurrence of maltase activity (the author's unpublished data). In $N$. cincticeps the cytoplasm of the III-cells are greatly occupied by the extremely convoluted and tangled intracellular canaliculi. Therefore, the cross sections of the III-cells showed typical alveolate features. From these characters the III-cells appear to serve both as the serous cells, as has been described by NASU (1963), and storage cells for the aqueous saliva. In $L$. striatellus the largest A-follicle seemed to elaborate digestive enzymes, for the cytological structure of the constituent cells had a strong resemblance to that of the III-cells of $N$. cincticeps and $T$. viridis. It was also probable that the E-follicle secreted serous substances. The function of the other kinds of the cells or the follicles, and the regulatory mechanism to control the type and amount of the secretions from each part were obscure in the present studies.

\section{Secretions of accessory gland}

So far there is little information available on the function of the accessory gland of leafhoppers. The present investigation showed that this gland was responsible for the elaboration of the saliva, and led to its probable functions. In $T$. viridis, the tail portion of the accessory gland bore histological resemblance to the Malpighian tubules of insects. Such histological resembrance was also found in $N$. cincticets. Its contents were non-proteinaceous clear fluids. In view of these evidences it was hypothetically assumed that the accessory gland appeared to absorb water and certain non-protein solutes from hemolymph by means of the asymmetric penetration of its wall. It may be noted in this connection that some recent investigations have shown that amino acids are an important constituent of the saliva of certain aphids (e. g. ANDERS, 1958; KLOFT, 1960; Schäller, 1960). Further NuORTEVA et al. (1961) has suggested that the salivary glands of Heteroptera are able to eliminate some toxic substances from the hemolymph. Also the histological appearance of the cephalic portion was suggestive of some function such as secretion or reabsorption. On the other hand, the accessory gland of L. striatellus was quite different from that of $N$. cincticeps or $T$. viridis in the histological structure and nature of the secretion. The fine granules contained in the large secretory cells were considered as the secretory products for their dynamic variation in number, and their intensive cyanophilic property was strongly suggestive of the presence of mucosubstances. Then, the accessory gland of L. striatellus seemed to play a part in the elaboration of the sheath material.

\section{Probable function of conducting parts}

The zonal differentiation were recognized in the epithelial cells of both the principal and the salivary ducts of $N$. cincticeps and $T$. viridis, by their histological sections. In the apical zone fine striations occur closely towards the chitinous wall of the ejaculatory canal. This cytological structure suggested reasonably that these ducts performed some function such as reabsorption other than a merely mechanical transportation of the saliva. In B. japonica the fact that the epithelium of these ducts included abundant colorable fine granules around the striated zone was more indicative of this assumption. 
In mammalian salivary glands it has been well known that the precursor saliva is subjected to the reabsorption of some part of salts and the secretion of bicarbonate by passing through the striated part of the duct. DAY (1951) has also sugested in Periplaneta americana that the ducts of the salivary glands, not of the reservoirs, play a part in the elaboration of the saliva. On the other hand, the accessory duct in $N$. cincticeps and $T$. viridis apparently functions only in conduction, although that of B. japonica may have some extra functions. Miles (1959, 1964) has stated that the accessory duct secretes mucoids and phenolase in certain Heteropterous species.

\section{SUMMARY}

The salivary secretions of leafhoppers are considerably important for their toxic effect on the host plant, and concerning the transmission of plant viruses. In the present paper morphological and histological studies were made on the salivary glands of the rice plant leafhoppers in order to help to throw light on their functions. Results obtained were summarized as follows :-

(1) The salivary glands were consisted of a pair of principal gland and accessory gland, and their conducting parts. In $N$. cincticeps and $I$. dorsalis, the principal gland was a compact mass made up of six kinds of secretory cells, and bilobed. It was characterized by the much smaller anterior lobe and the six large III-cells of the posterior lobe. The accessory gland was extremely short and bent tubular gland. In L. striatellus, S. furcifera and $N$. lugens, the principal gland was an aggregate body consisted of eight kinds of follicle that were made up of a small number of secretory cell. The accessory gland was a bi-cellular gland being somewhat constricted spherical in shape.

(2) With histological staining it was demonstrated that each kind of secretory cells in $N$. cincticeps and follicle of L. striatellus had distinctly different cytological structures suggesting their different functions (TextFigs. 2 and 4; Tables 1 and 2). It was considered at least that the IV-cells of $N$. cincticeps and the A-follicle of L. striatellus produced digestive enzymes, and that the $\mathrm{V}$-cells of $N$. cincticeps served as one of the sources of the sheath material.

(3) In $N$. cincticeps the accessory gland was divided into two portions, the head and tail portions. The tail portion was resembled in structure to the Malpighian tubules, and it was hypothetically assumed that this portion absorbed selectively certain non-protein solutes from hemolymph. In $L$. striatellus the accessory gland was regarded as a main source of the sheath material.

(4) Both the principal as well as the salivary ducts seemed to perform some function other than a mechanical transport of the secretions.

\section{ACKNOWLEDGMENT}

The author would like to express his acknowledgment to Prof. Kisabu IYA Tom for his. continuous interest and encouragement during these experiments. The author is indebted to Dr. Sôchô NASU, of National Institute of Agricultural Sciences, for his helpful advice during the preparation of the manuscript.

\section{REFERENCES}

Anders, F. (1958) Experientia 14:62.

BAptist, B. A. (1941) Quart. J. Micr. Sci. $83: 91 \sim$ 139.

Bugnion, E. (1907) Ball. Ent. Soc. France, 1907 : $347 \sim 350$.

Bugnion, E. and N. Popoff (1908) Arch. Anat. Micr. $10: 227 \sim 268$.

Bugnion, E. and N. Popoff (1910) Arch. Anat. Micr. $11: 435 \sim 456$.

CARTER, W. (1962) "Insects in relation to plant disease". Interscience Publishers, New York.

Dовroscкy, I. D. (1931) Contrib. Boyce Thompson Inst. $3: 39 \sim 58$.

DAY, M. F. (1951) Aust. J. Res. B, $2: 421 \sim 427$.

DAy, M F., H. IRzykiewicz and A. Mckinnon (1952). Aust. J. Sci. Res. B, $5: 128 \sim 142$.

Gil-Fernandez, C. and L. M. Black (1965) Ann. Ent. Soc. Am. $58: 275 \sim 284$.

Herford, G. V. B. (1935) Ann. appl. Biol. $22: 301 \sim$ 306.

KLoft, W. (1960) Z. angew. Ent. 45:337〜381. 
Leston, D., J. G. Pendergrast and T. R. E. Southwood (1954) Nature $174: 91 \sim 92$.

Miles, P. W. (1959) J. Ins. Physiol. $3: 243 \sim 255$.

Miles, P. W. (1959 a) Nature $183: 756$.

Miles, P. W. (1960) J. Ins. Physiol. $4: 209 \sim 219$.

Miles, P. W. (1960 a) J. Ins. Physiol. $4: 271 \sim 282$.

Miles, P. W. (1961) Nature $191: 911 \sim 912$.

Miles, P. W. (1964) J. Ins. Physiol. $10: 121 \sim 129$.

Miу амото, S. (1961) Sieboldia $2: 197 \sim 259$.

Nasu, S. (1963) Bull. Kyushu Agr. Exp. Station 8 : $153 \sim 349$.

Nuorteva, P. (1956) Ann. Ent. Fenn. 22:45 54.

Nuorteva, P. (1956 a) Ann. Ent. Fenn. $22: 103 \sim 108$.

Nuorteva, P. and S. Laurema (1961) Ann. Ent. Fenn. $27: 57 \sim 65$.

SaxenA, K. N. (1954) Experientia 10:383 384.

SAXenA, K. N. (1955) J. Zool. Soc. India $7: 41 \sim 52$.

Sch ̈̈LlER, G. (1960)Ent. exp. appl. $3: 128 \sim 136$.

Sмiтн, F. F. (1933) J. Agr. Res. $47: 475 \sim 485$.

Soutнwood, T. R. E. (1955) Tijdschr. Ent. 98:77 84.

Storey, H. H. (1939) Proc. Roy. Soc. Lond. B, 113 : 463 485.

Willis, D. M. (1949) Proc. Zool. Soc. Lond. 118 : $984 \sim 1001$.

\section{EXPLANATION OF PLATES}

Plate I. Salivary glands of Nephotettix cincticeps Uhler (Deltocephalidae) (Figs. 1 and 2) and Tettigella viridis LinNé (Tettigellidae) (Fig. 3). The anterior lobe is blackened.

Plate II. Salivary glands of the species belonging to Deltocephalidae and related families. The anterior lobe is blackened.

Fig. 1 Bothrogonia japonica Ishinara (Tettigellidae)

Fig. 2 The same as above, a side view of the principal gland

Fig. 3 Usuironus limbifer Matsumura (Deltocephalidae)

Fig. 4 Macrosteles fascifrons $\mathrm{STA}_{\mathrm{T}}$ (Deltocephalidae)

Fig. 5 Hishimonus sellatus Ishinara (Deltocephalidae)

Fig. 6 Chlorita flavescens FABricius(Cicadellidae)

Fig. 7 Erythroneura limbata Matsumura (Cicadellidae)
Plate III. Salivary glands of the species belonging to Delphacidae.

Fig. 1 Sogatella frucifera HoRvátH

Fig. 2 Laodelphax striatellus FaLLÉN

Fig. 3 Nilaparvata lugens ST $\mathrm{S}_{\mathrm{L}}$

Fig. 4 Delphacodes albifascia Matsumura

Fig. 5 Tropidocephala brunnipennis SignoreT

Fig. 6 Delphax crassicornis PANzer

Plate IV. Histological structures of accessory gland and ducts.

Fig. 1 The cross section of the head portion (N. cincticeps)

Fig. 2 The longitudinal section of the tail portion (do.)

Fig. 3 The cross section of the tail portion(do.)

Fig. 4 The cross section of the head portion (T. viridis)

Fig. 5 The longitudinal section of the tail portion (do.)

Fig. 6 The cross section of the tail portion(do.)

Fig. 7 The longitudinal section of the principal duct ( $N$. cincticeps)

Fig. 8 The cross section of the principal duct (do.)

Fig. 9 The cross section of the accessory duct (do.)

Plate V. Photographs of salivary glands.

Fig. 1 Nephotettix cincticeps UHLER (adult male) (Deltocephalidae)

Fig. 2 The same as above (last inster nymph female)

Fig. 3 Stenocranus minutus FABRIcIUs (Delphacidae)

Fig. 4 Laodelphax striatellus Fallén (Delphacidae)

Plate VI. Histological sections of salivary glands of $N$. cincticeps.

Plate VII. Various kinds of secretory cells of the principal gland of $T$. viridis.

Fig. 1, I-cell ; Fig. 2, II-cell ; Fig. 3, III-cell ; Fig. 4, IV-cell; Fig, 5, V-cell ; Fig. 6, VI-cell.

Plate VIII. Histological sections of salivary glands of L. striatellus.

Plate IX. Histological sections of salivary glands of $T$. viridis.

Plate X. Histological sections of salivary glands of L. striatellus. 


\section{摘要 \\ 稲ウンカ・ヨコバイ類の唾腺に関する研垫}

第 1 報 形態と組織棈造

$$
\text { 寒 川 - 成 }
$$

名古屋大学農学部害虫学教室

半翅目昆虫の睡腺分泌物は植物体におよぼす種々の影 響，およびウイルス病の媒介などに関連する重要な諸問 題を包含している。本研究はそれらの研究に先だち, ま ず我国の稻作上きわめて重要な害虫であるツマグロヨコ バイ,イナヅマヨコバイ,セジロウンカ, ヒメトビウンカ およびトビイロウンカを中心にウンカ， ヨコバイ類の唾 腺の形態と組織構造を詳細に検討したものである。唾腺 の形態は昆虫細胞用クラーク液中で摘出された唾腺にト ルイジン青または中性赤の稀薄水溶液で超生体染色をほ ぞこし顕微鏡下で観察された。組織構造はブアン, アレ ンブアンまたはスサ液で固定され，アザンあるいはデラ フィルドのヘマトキシリンーエオシン染色をほどてされ た切片標本によって諰べられた。その結果は次のとおり である。

1. ウンカ, ヨコバイ類の唾腺は一対の主腺之副腺, および分泌管系から形成されている。

2. ヨコバイ類の主腺は6種類の腺細胞群の集合体で,
2 葉に分けられている。副腺は尼折した短管状である。

3. ウンカ類の主腺は数種類の小胞状組織に分離され ている。各組織は少数の同種の腺細胞で形成されてい る。副腺は球状である。

4. 唾腺の形態は後胚子発育の各時期をとおしてほと んど変化を示さなかった。

5. 主腺を形成する腺細胞群あるいは小胞状組織の細 胞質の性状および色素に対する着染性に顕著な相違が認 められた。

6. ヨコバイ類の主腺のIV型細胞とウンカ類の主腺の $\mathrm{A}$ 型組織は消化䣼素の主要な産生組織と考えられた。

7. ヨコバイ類の主腺の $\mathrm{V}$ 型細胞とウンカ類の副腺は 口針鞘形成物質の主要な産生組織と考えられた。

8. ヨコバイ類の副腺の䍡部はマルピーギ管様の組織 構造を示した。

9. 分泌管の上皮細胞の構造はある種の生理的機能の 存在を暗示した。
抄

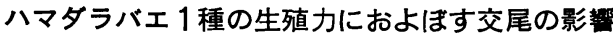

Neilson, W.T.A. and J. W. McAlran (1964) Artificial diets for the apple maggot, Rhagoletis pomonella (W $\mathrm{ALSH}$ ) II. Reproductive portential. J.

Econ. Ent. 57 : 904 905.

Neilson, W.T.A. and J. W. McAllan (1965) Effects of mating on fecundity of the apple maggot, Rhagoletis pomonella (W $\mathrm{W}_{\mathrm{ALSH}}$ ). Canad. Ent. 97: 276 279.

著者らはさきに一生の間何回も交尾した八マダラバエの继 はそろでないものよりも多数の卵を産むことから，交尾は産卵 を刺激するといろ暗示をえたが，今回これについて再実験した。 すなわち 9 カ月間 $4.5^{\circ} \mathrm{C} て ゙$ 眝蔵したさなぎからえた数百の成虫 を $21^{\circ} \mathrm{C}, 80 \%$ の温湿度て飼育し, sucrose, enzymatic soy hydrolysate, Brewer's yeast U.S.P., ミネラル(Salt Mixture No. 2, U.S.P. XIII) 拉よび水を与えて交尾をまち，交尾後は 1 対ごとに別なかごと移してリンゴに産卵させた。この間 1 日 飞30 回位交尾を観察し，1部からは途中で雌を除き，他は死亡 するまで雌雄を一緒にした。この結果一生を通して交尾した雌 と最初の 2 週間飞数回しかこれを行なわなかったものの平均産 卵数は 395:360 となり，一方全産卵数炕対する有精卵率は前者 の 95\%対して後者は $46 \%$ 亿止まった。この場合の有精卵の産 卵経過をみると，最初の 2 週間では有精卵のわりあいと差はな く，つぎの 7 週間では交尾を限定された雌のそれが急減し，9週 間後飞は後者の有精卵は皆無となった。このことから交尾は期 待されるほど産卵または卵巣内での卵発㕕を刺激するものでは なく,むしろ有精卵のわりあい関係することがわかった。乙 かし本種の雌は非常飞雑婚する習性があり，1頭で繁殖力のある 雄と数回交尾するから，不妊雄の放飼による侵害の根絶をはか ることにはあまり期待がかけられない。(岐阜大農 福島正三) 

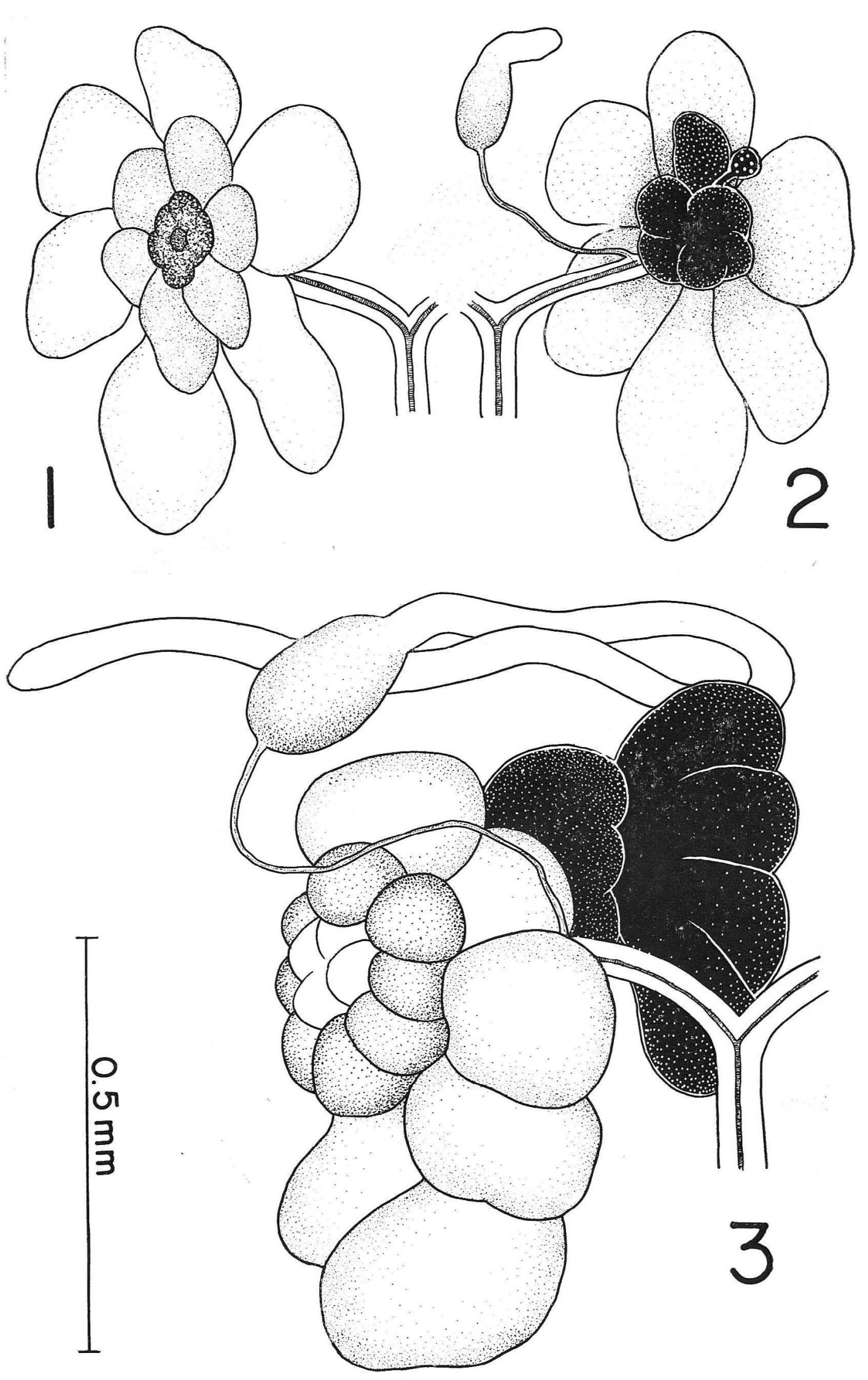


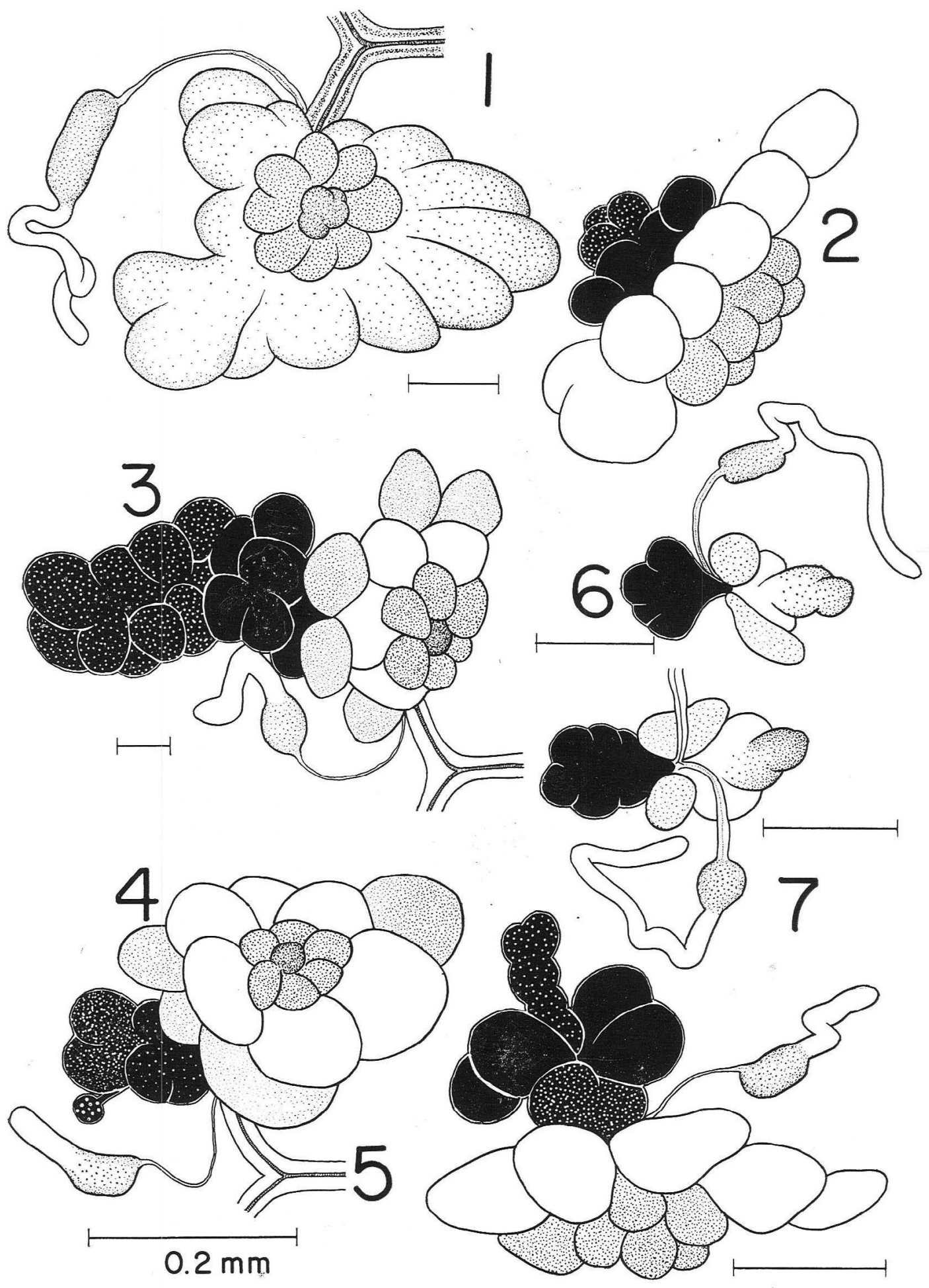




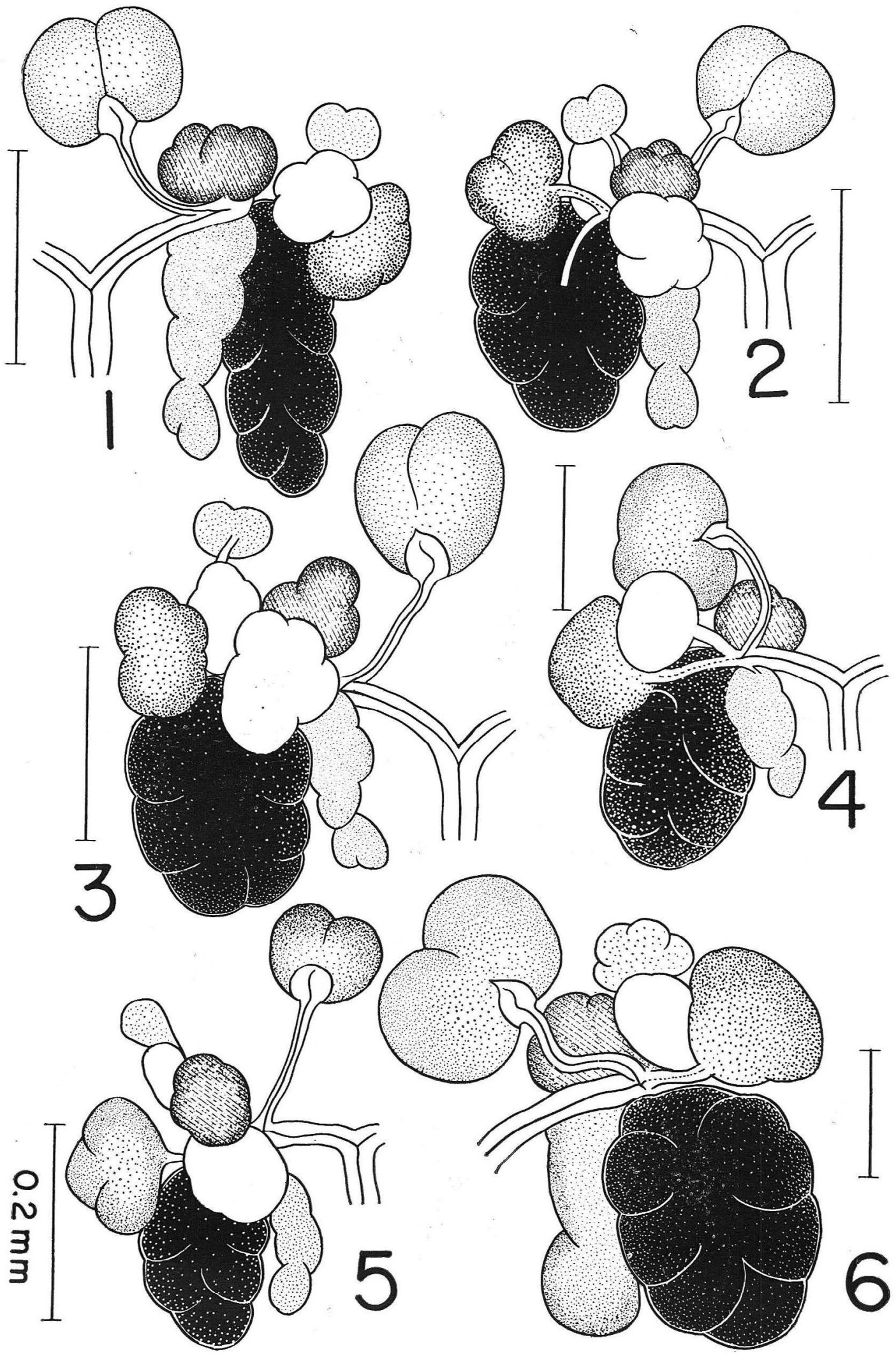



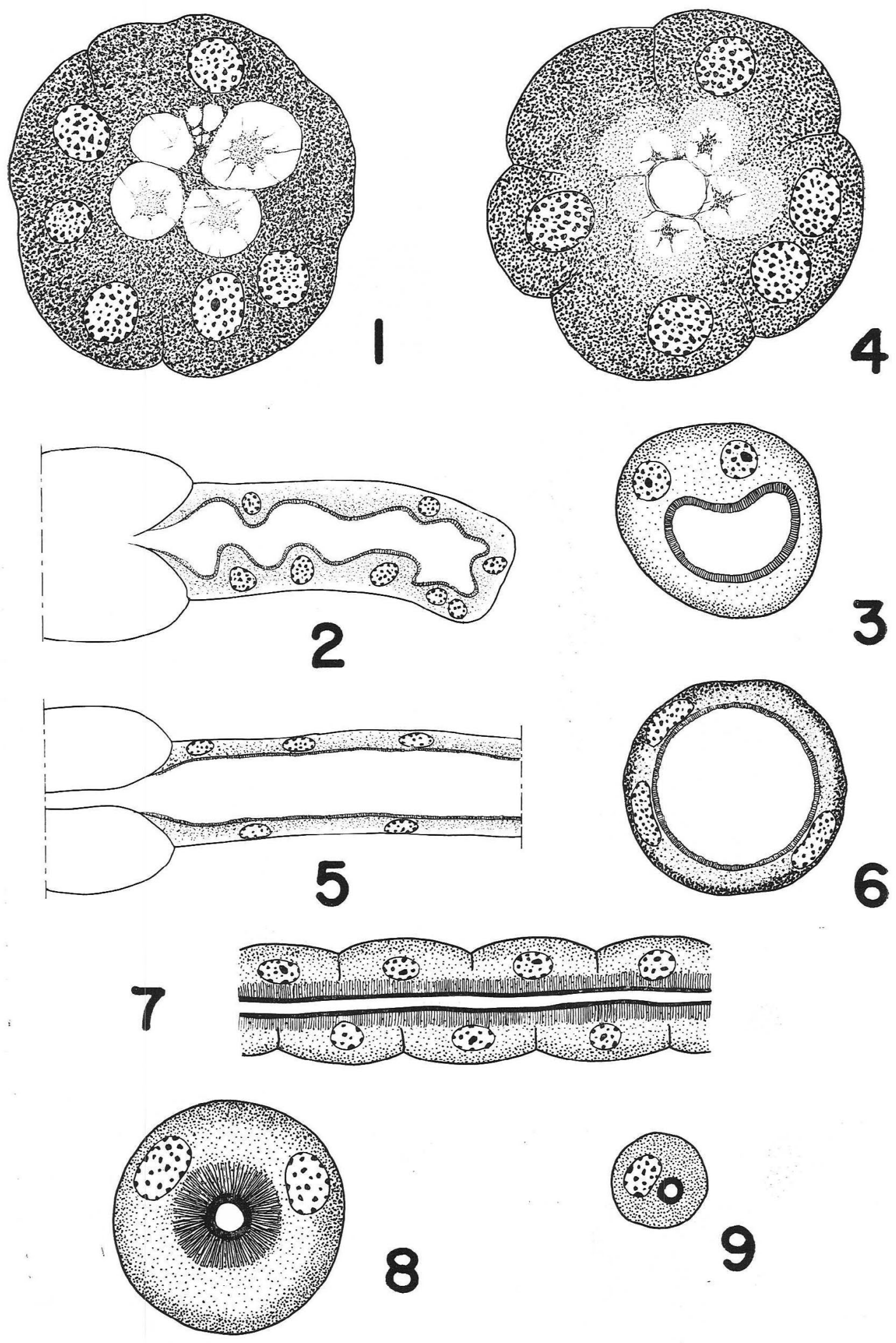

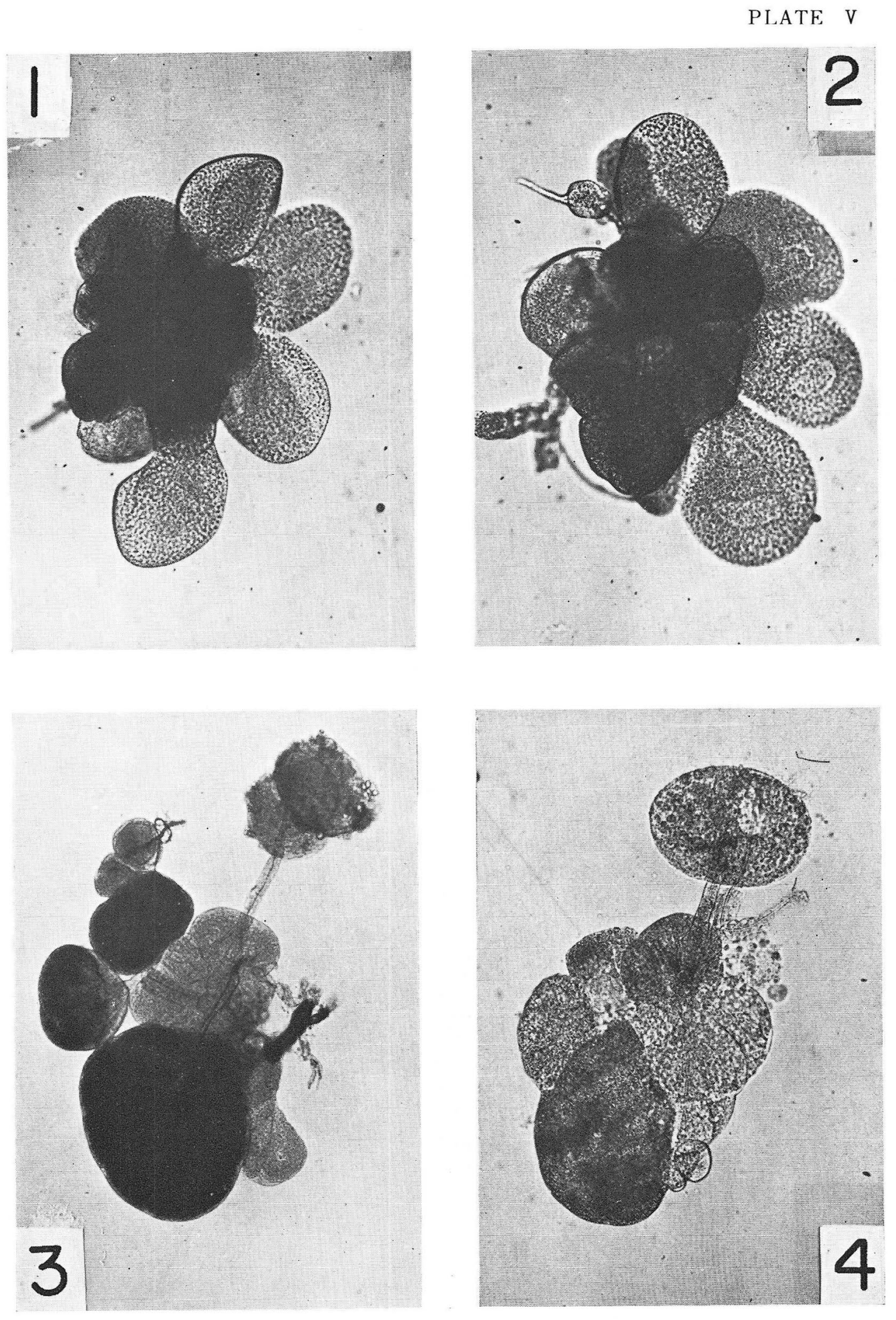
PLATE VI
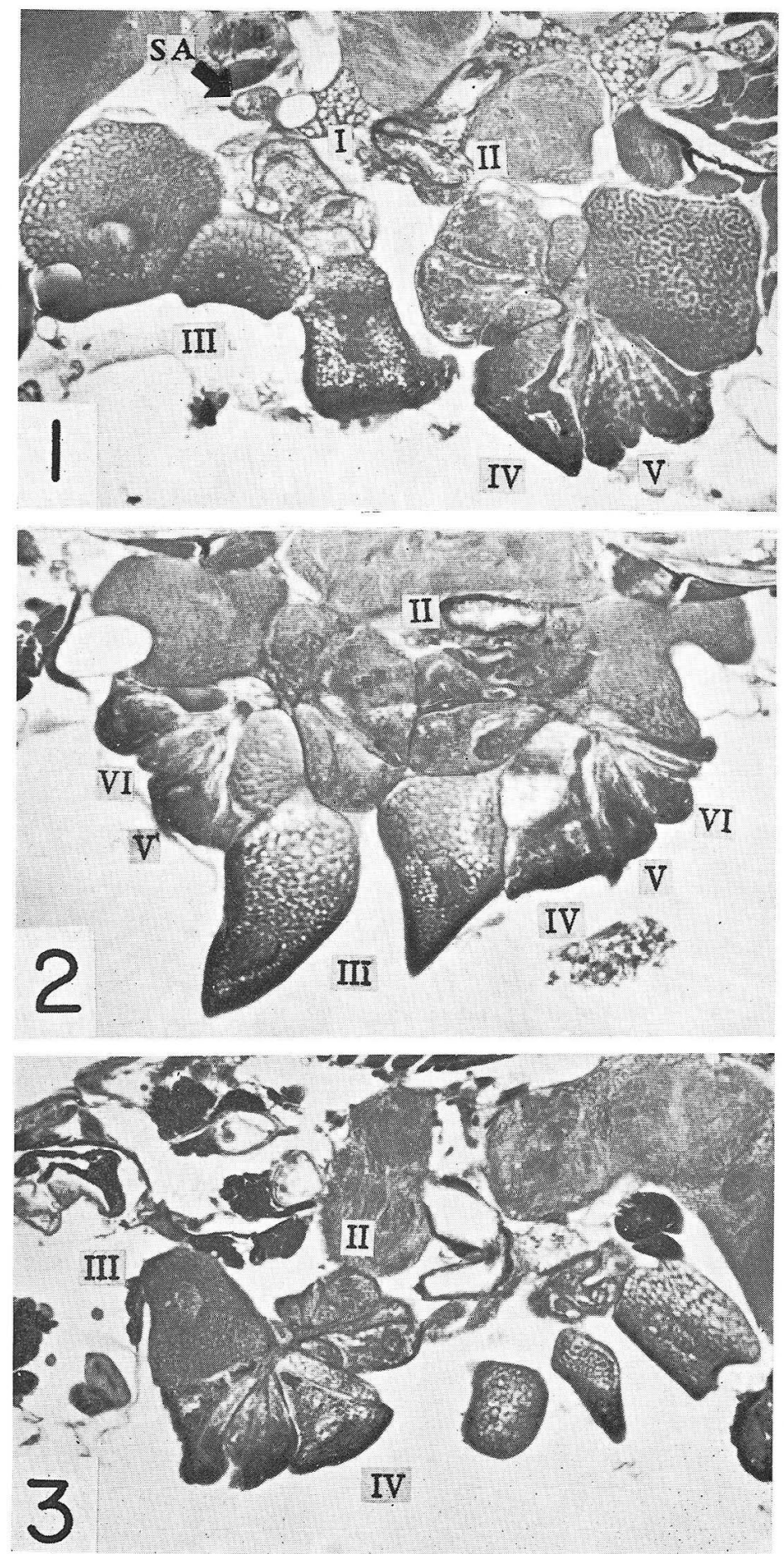
PLATE VII
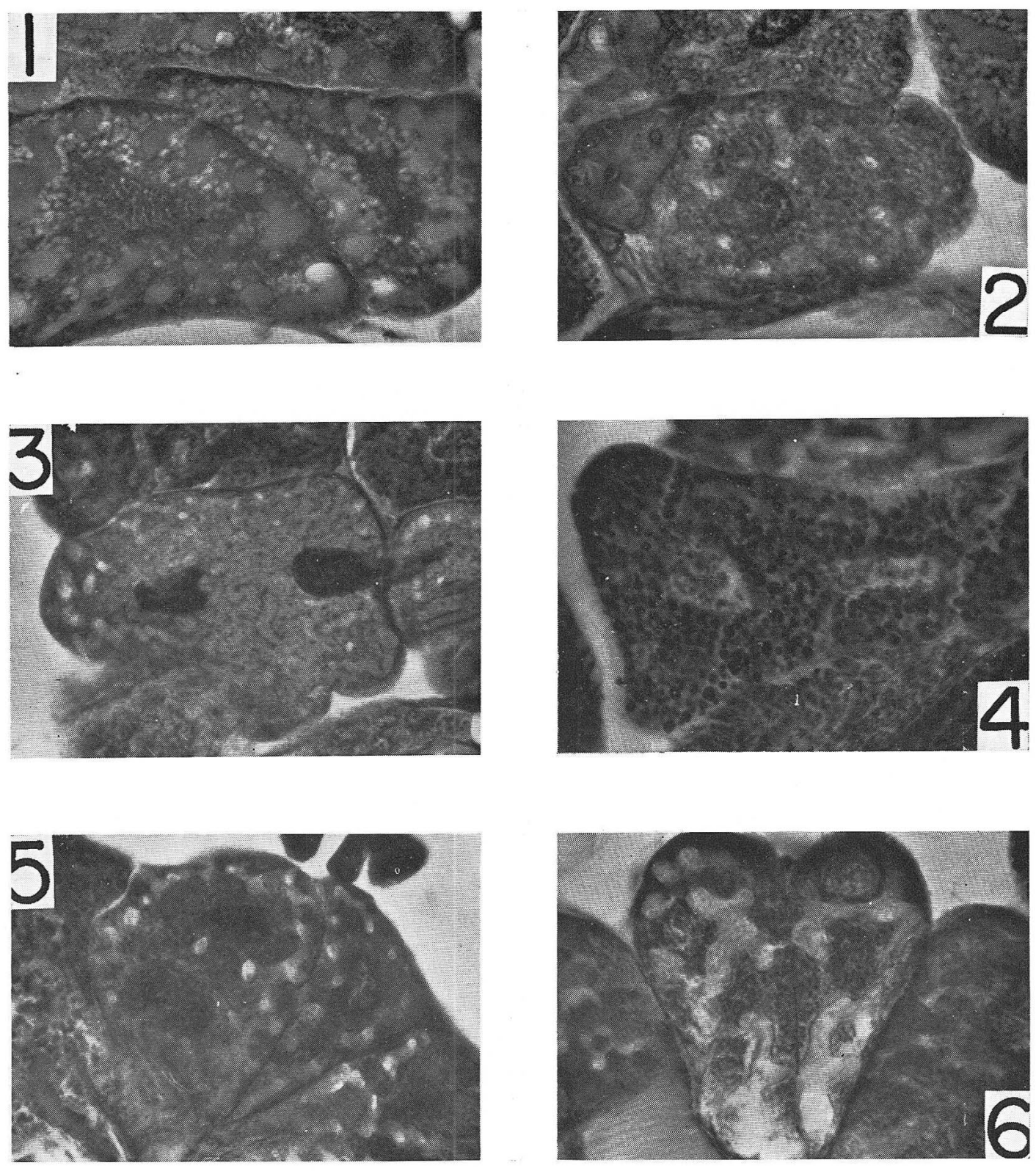

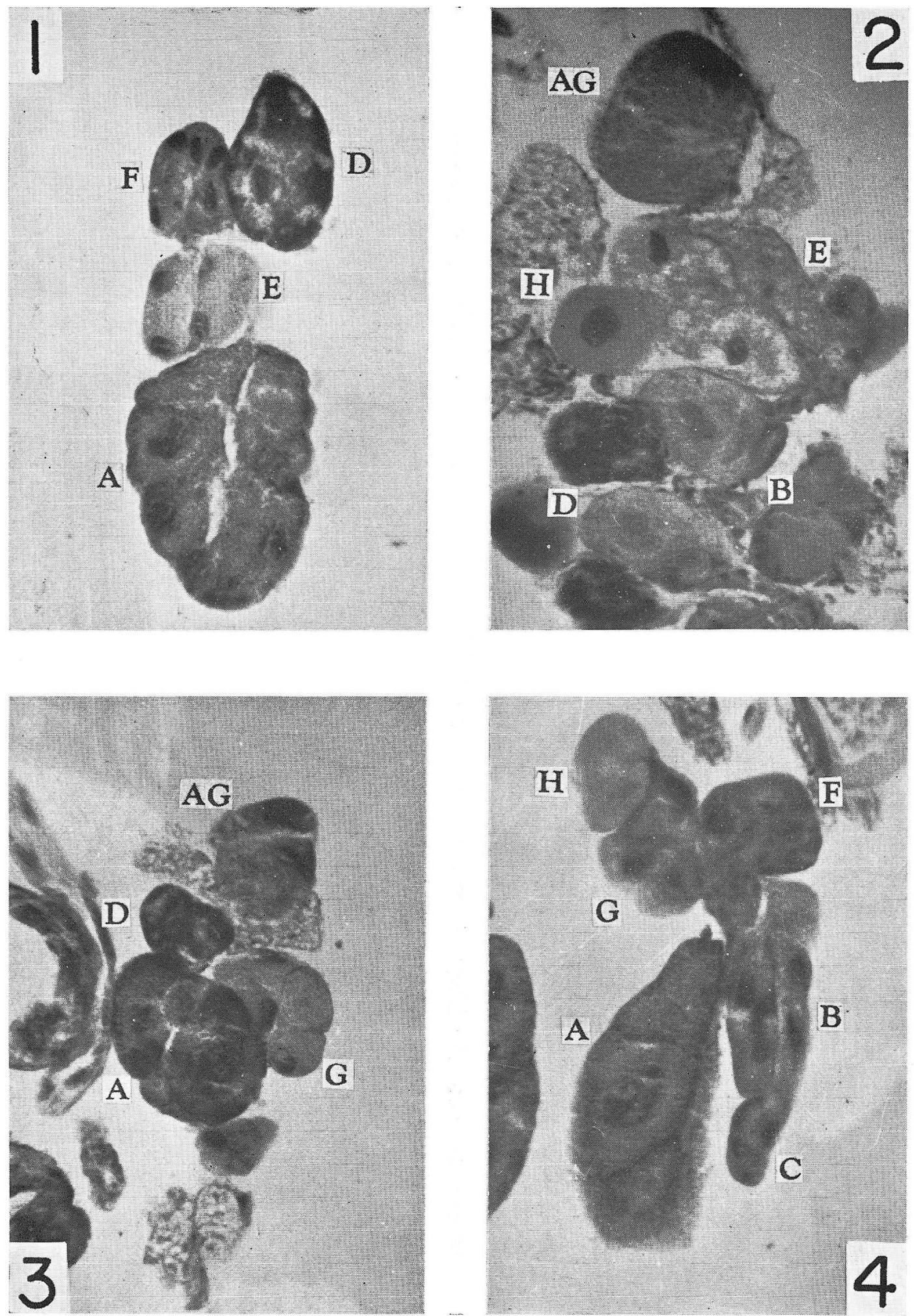


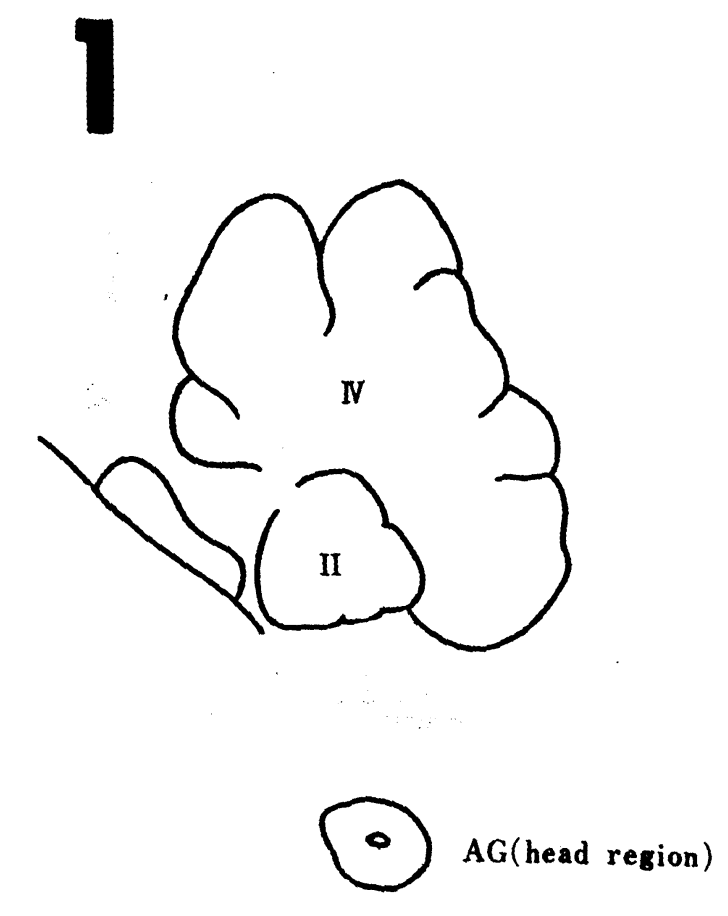

2
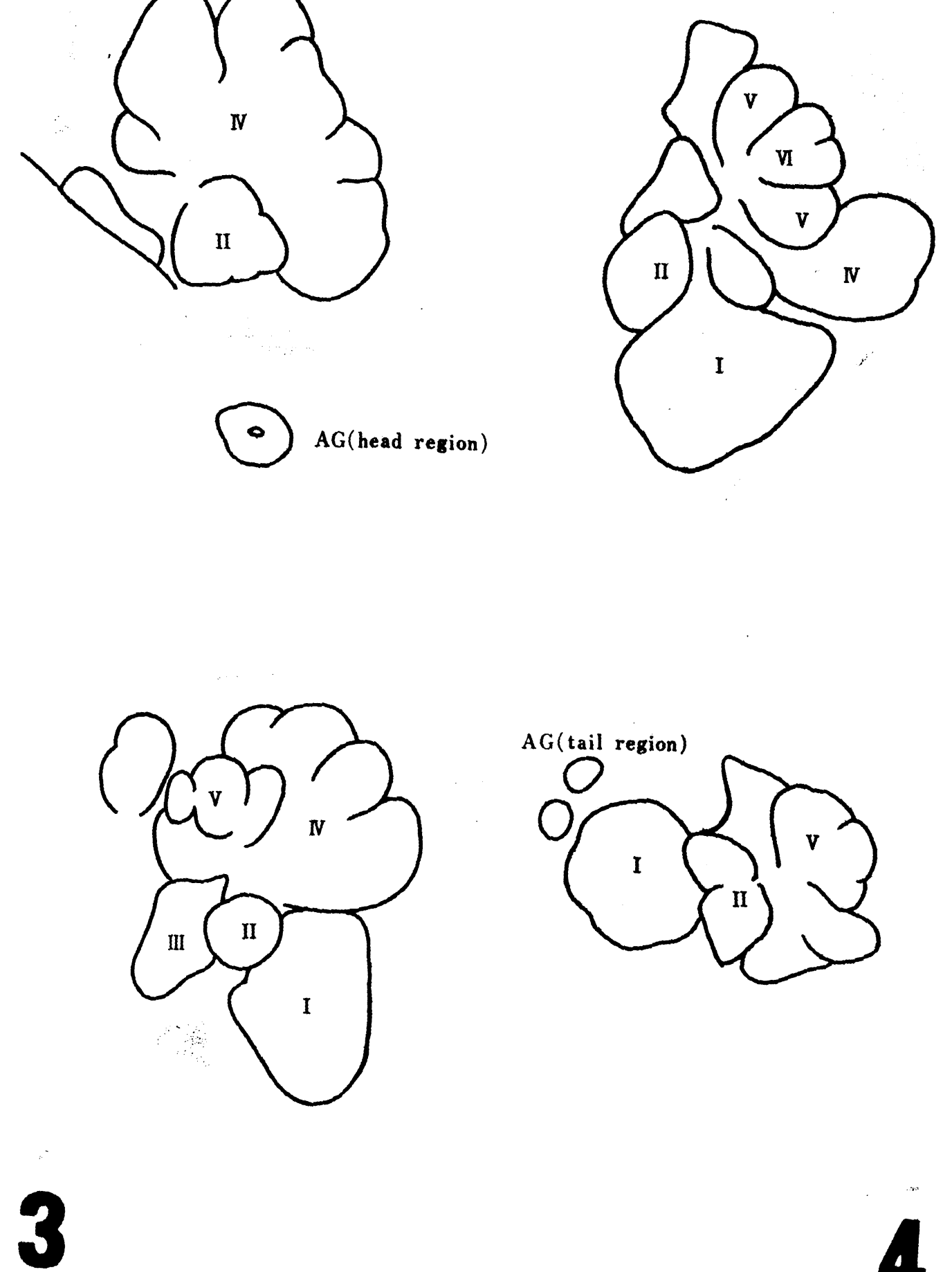

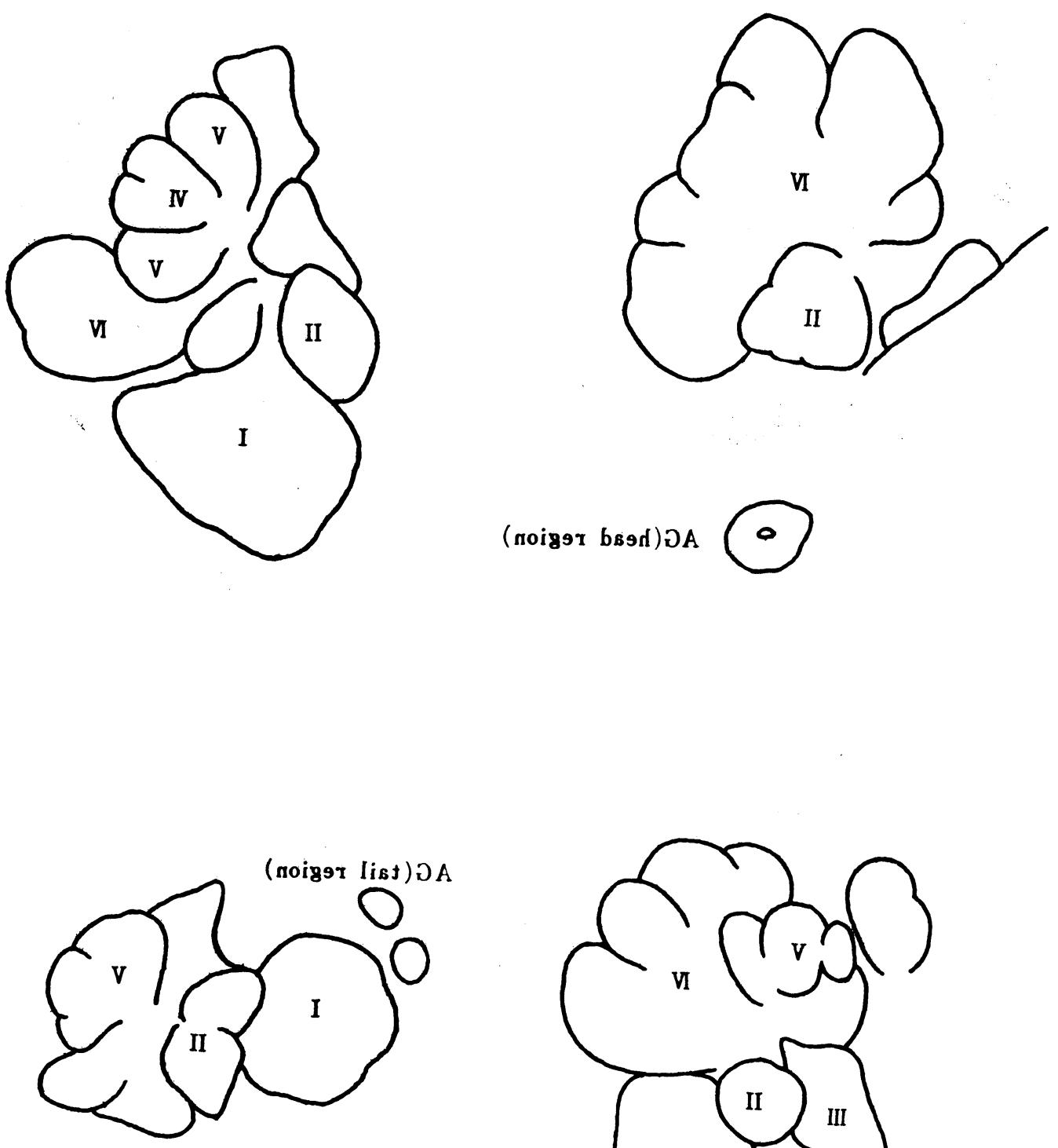

$($ noiget bagh)Da 0

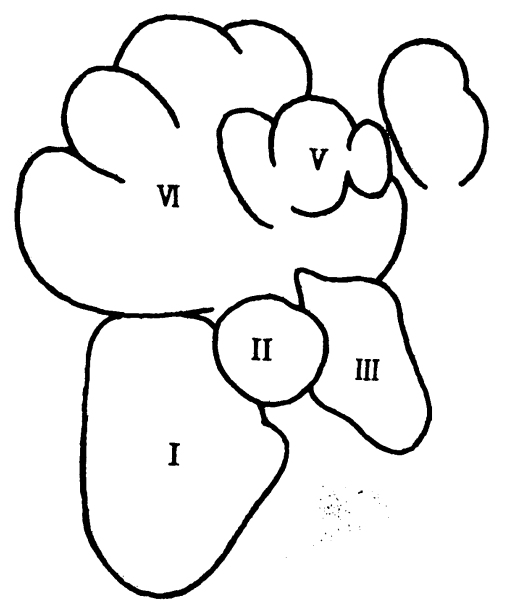


PLATE IX
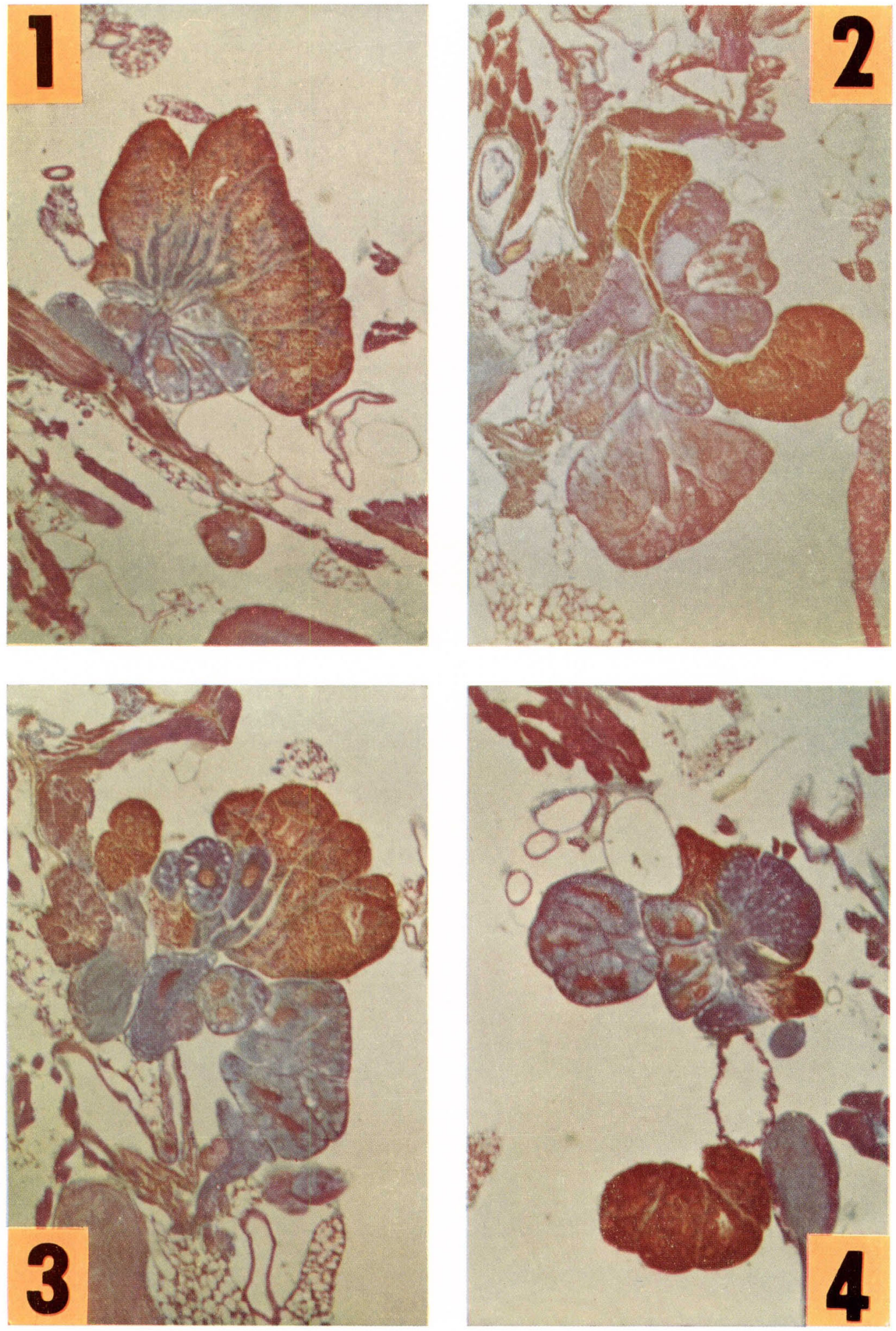

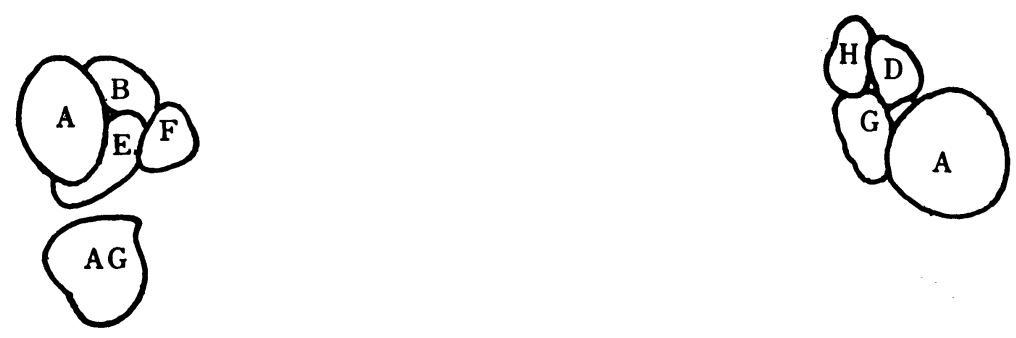

2
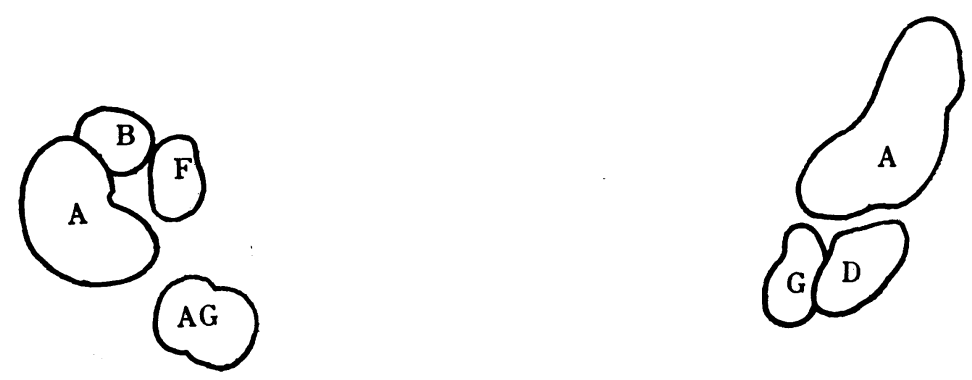

4

3

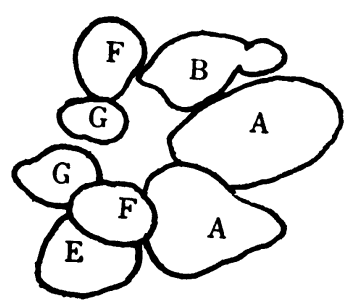

8 

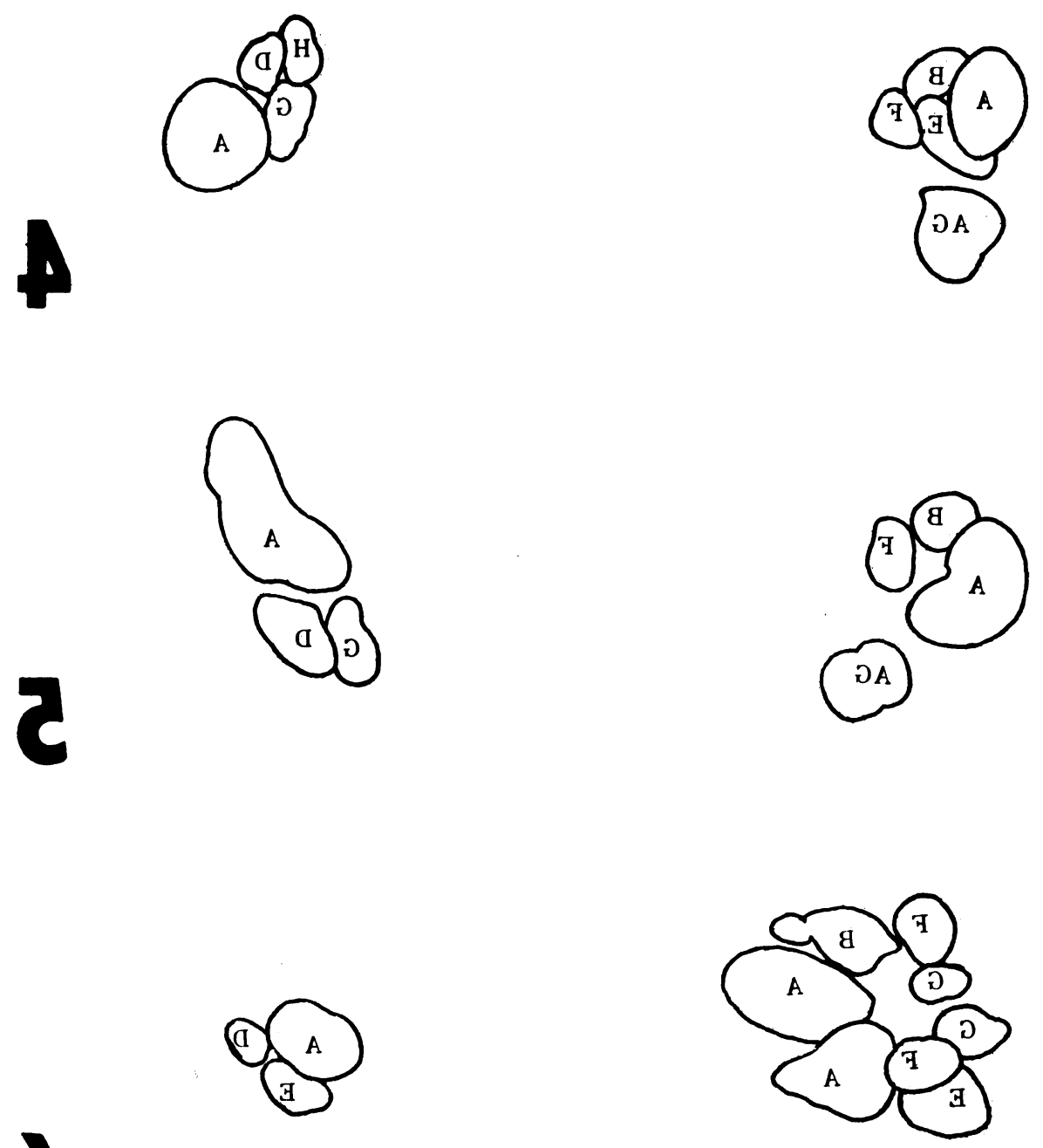

d

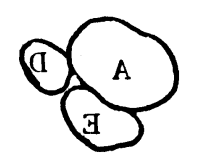


PLATE X
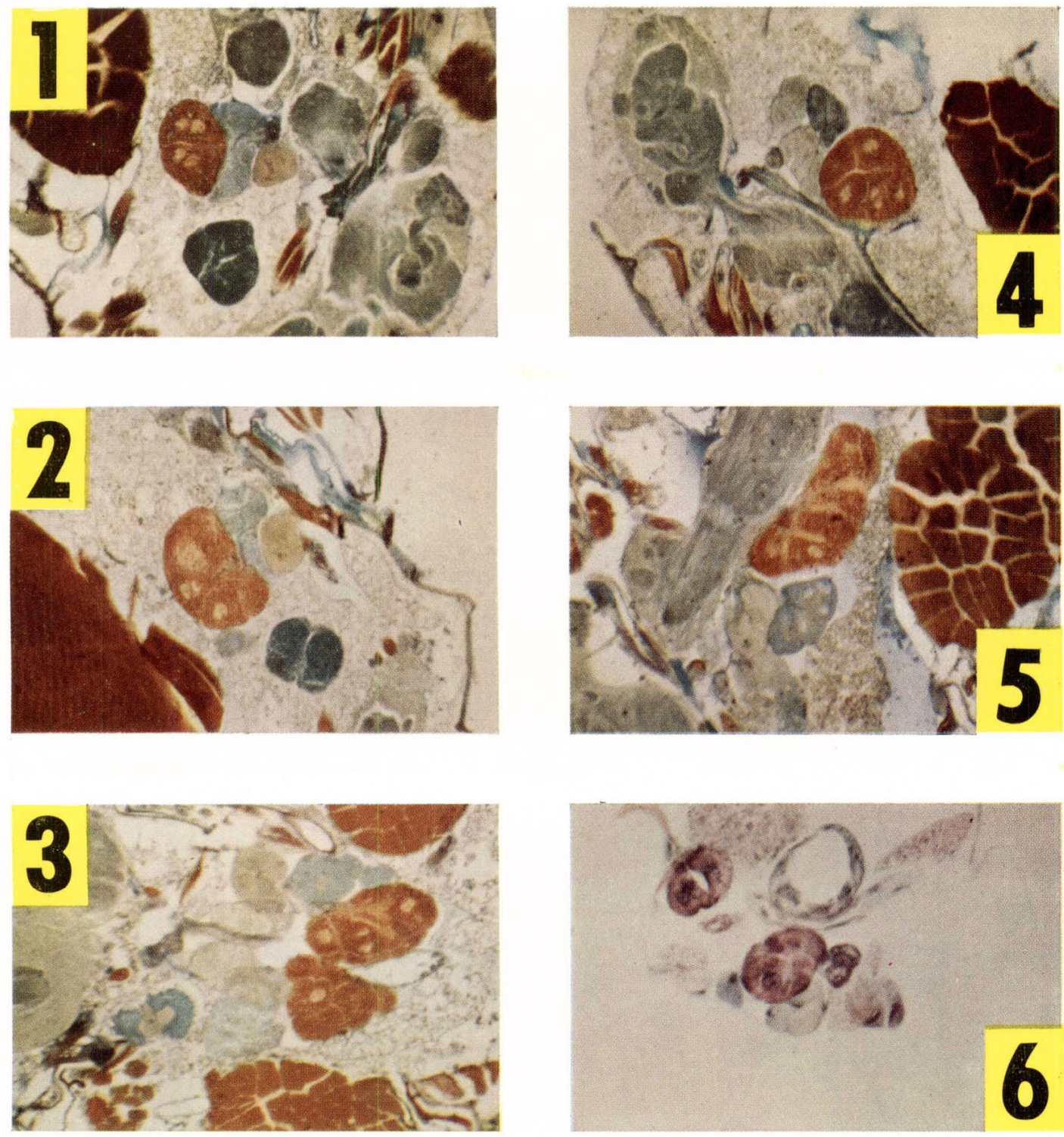